\title{
Sistem Informasi Persediaan Obat di Puskesmas Sepatan Tangerang
}

\author{
Yusuf Amerta ${ }^{1)}$, Mira Ziveria ${ }^{2)}$ \\ 1) Sistem Informasi, Fakultas Industri Kreatif Institut Teknologi dan Bisnis Kalbis \\ J1. Pulomas Selatan kav.22, Jakarta Timur, Daerah Khusus Ibukota Jakarta 13210 \\ Email: yusuf.amerta@gmail.com \\ Email:mira.ziveria@kalbis.ac.id
}

\begin{abstract}
Sepatan Health Center is a facility or health service agency that serves for the health of the community on district Sepatan, at this place there is a pharmacy which is a container medicine. As a function of accelerating and facilitate the activities of drug data management, it needs technology that is implemented in the health service agency that is Sepatan Tangerang Health Center. The purpose of this research is to build the Information System of Drug Inventory at Sepatan Tangerang Public Health Center with web based by using Prototype development method which starts with flowchart analysis, design using UML Diagram and PHP programming language and MySQL database and test with Black Box. The result of this research is a Drug Inventory Information System that can perform the process of drug data input transactions, receipt transactions, location change transactions, expense transactions and booking transactions and generate a good report of each transaction made.
\end{abstract}

Keywords: information system, medicine, prototype, public health center, stock

\begin{abstract}
Abstrak: Puskesmas Sepatan merupakan fasilitas atau badan pelayanan kesehatan yang menyelenggarakan upaya kesehatan untuk masyarakat tingkat kecamatan Sepatan, pada puskesmas ini terdapat bagian Farmasi yang bertugas mengelola obat. Sebagai fungsi mempercepat dan mempermudah kegiatan pengelolaan obat maka dibutuhkan teknologi yang diimplementasikan pada badan pelayanan kesehatan yaitu pada bagian Farmasi di Puskesmas Sepatan Tangerang. Penelitian ini bertujuan untuk membangun Sistem Informasi Persediaan Obat di Puskesmas Sepatan Tangerang berbasis web dengan menggunakan metode pengembangan Prototype yang dimulai dengan analisis menggunakan flowchart, perancangan menggunakan UML Diagram dan bahasa pemrograman PHP dan basis data MySQL serta pegujian dengan Black Box. Hasil dari penelitian ini adalah sebuah Sistem Informasi Persediaan Obat yang dapat melakukan proses transaksi input data obat, transaksi penerimaan, transaksi perubahan lokasi, transaksi pengeluaran dan transaksi pemesanan serta menghasilkan laporan yang baik dari setiap transaksi yang dilakukan.
\end{abstract}

Kata kunci: Obat, persediaan, prototipe, puskesmas, sistem informasi

\section{PENDAHULUAN}

Perkembangan teknologi pada saat ini sangat mempengaruhi setiap lini kehidupan dan pemanfaatannya diperlukan oleh setiap organisasi baik dalam bentuk sosial masyarakat maupun perusahaan, baik perusahaan kecil, menengah maupun besar. Maka dari itu implementasi dan penerapan teknologi sangat diperlukan agar proses berjalannya aktifitas dapat dipercepat dan dipermudah. Pesatnya perkembangan teknologi informasi yang ada saat ini ditandai dengan banyaknya proses komputerisasi dalam setiap kegiatan kehidupan, penggunaan komputer sudah tidak lagi dianggap sebagai pelengkap semata namun sudah dianggap sebagai kebutuhan, salah satunya dalam proses pengelolaan data dan pelaporan transaksi pada kegiatan inventori.

Kegiatan inventori atau persediaan merupakan proses pengolahan data barang yang terdapat di dalam suatu gudang. Sistem persediaan memiliki pengaruh besar terhadap suatu instansi karena sistem persediaan dapat membantu menyelesaikan masalah pengolahan data barang dan memudahkan pelaporan data barang yang tersedia. Salah satu contoh kegiatan inventori yaitu pengelolaan persediaan obat, kegiatan ini biasa dilakukan oleh badan pelayanan kesehatan seperti Rumah sakit, Puskesmas dan Apotek.

Salah satu badan pelayanan kesehatan yaitu Puskesmas Sepatan. Puskesmas inimerupakan fasilitas pelayanan kesehatan yang menyelenggarakan upaya 
kesehatan untuk masyarakat di kecamatan Sepatan. Puskesmas Sepatan berada di Jalan Raya Mauk Km 11 Kecamatan Sepatan Kabupaten Tangerang dan dipimpin oleh dr. Elni Handayani. Pada Puskesmas ini terdapat bagian farmasi yang bertugas memproses pengelolaan obat dan yang bertugas sebagai koordinator bagian farmasi adalah ibu Lisdiyanti atau yang dapat disebut sebagai petugas farmasi.

Menurut ibu Lisdiyanti proses pengelolaan obat yang berjalan di Puskesmas Sepatan dilakukan secara manual dimana proses pencatatan setiap transaksi dilakukan pada kartu stok dan buku registrasi obat secara manual. Terdapat kelemahan yang disampaikan oleh beliau yaitu proses yang dilakukan memakan waktu lama dan kegiatan pengarsipan tidak efisien, selain itu terdapat kendala pada saat melakukan pembuatan laporan pemakaian dan lembar permintaan obat (LPLPO) dan laporan Narkotika pada akhir bulan karena data yang dibutuhkan sangat banyak berdasarkan data transaksi yang terjadi selama satu bulan sehingga proses pencarian data arsip dilakukan satu-persatu sehingga membutuhkan waktu yang lama dan tidak efisien.

Sebagai fungsi mempercepat dan mempermudah kegiatan transaksi dan pengelolaan data obat maka dibutuhkan teknologi yang diimplementasikan pada badan pelayanan kesehatan ini. Implementasi teknologi dilakukan dengan mengembangkan sistem informasi persediaan obat pada bagian Farmasi di Puskesmas Sepatan, pengembangan akan dilakukan dengan teknologi berbasis web yang dibangun menggunakan bahasa pemrograman PHP dan menggunakan basis data MySQL, teknologi ini dipilih karena bersifat dinamis sehingga mudah dalam proses pengembangan dan proses perbaikan pada saat penambahan fungsi atau pada saat terjadi suatu masalah.

Berdasarkan uraian tersebut, rumusan masalah yang diusulkan adalah bagaimana membangun sebuah sistem informasi persediaan obat pada Puskesmas Sepatan sehingga dapat membantu petugas dalam proses pengelolaan data yang meliputi proses penerimaan, proses perubahan lokasi, proses pengeluaran, proses pemesanan, proses pencarian dan proses pelaporan obat yang sudah terdapat di Puskesmas Sepatan?.

Dan berdasarkan perumusan masalah tersebut, maka tujuan penelitian adalah untuk membangun sistem informasi persediaan obat yang dapat memudahkan dan mempercepat proses pencarian data, transaksi input data obat, transaksi penerimaan, transaksi perubahan lokasi, transaksi pengeluaran dan transaksi pemesanan serta menghasilkan laporan yang baik dari setiap transaksi yang dilakukan.

\section{METODE PENELITIAN}

Pada metode penelitian akan menjelaskan teori pendukung, kronologis penelitian, termasuk desain penelitian, prosedur penelitian dan cara untuk menguji sistem informasi yang dikembangkan.

\section{A. Sistem Informasi}

Sistem informasi merupakan sistem yang mengatur suatu organisasi atau perusahaan dalam mengolah informasi-informasi yang dibutuhkan pada saat menjalankan proses kegiatan bisnis serta mendukung kegiatan operasional perusahaan sehingga informasi dapat tersampaikan dengan cepat, lengkap dan akurat [1].

\section{B. Persediaan}

Persediaan dapat diartikan sebagai barangbarang yang disimpan untuk digunakan atau dijual pada masa atau periode yang akan datang. Persediaan terdiri dari persediaan bahan baku, persediaan bahan setengah jadi dan persediaan barang jadi. Persediaan bahan baku dan bahan setengah jadi disimpan sebelum digunakan atau dimasukkan ke dalam proses produksi, sedangkan persediaan barang jadi atau barang dagangan disimpan sebelum dijual atau dipasarkan. Dengan demikian setiap perusahaan yang melakukan kegiatan usaha umumnya memiliki persediaan [2].

\section{Sistem Persediaan}

Sistem inventory atau sistem persediaan adalah suatu kegiatan dalam proses pengolahan data barang yang terdapat di dalam suatu gudang. Sistem persediaan memiliki pengaruh besar terhadap suatu instansi, karena sistem persediaan dapat membantu menyelesaikan masalah pengolahan data barang dan memudahkan pelaporan data barang yang tersedia.

\section{Obat}

Obat adalah suatu bahan atau campuran bahan yang dimaksudkan untuk digunakan dalam menentukan diagnosis, mencegah, mengurangi, menghilangkan, menyembuhkan penyakit atau gejala penyakit, luka atau kelainan badaniah atau rohaniah pada manusia atau hewan, termasuk memperelok tubuh atau bagian tubuh manusia. Meskipun obat dapat menyembuhkan penyakit [3]. Bahan obat jarang diberikan sendiri-sendiri, lebih sering merupakan 
suatu formula yang dikombinasi dengan satu atau lebih zat yang bukan obat yang bermanfaat untuk kegunaan farmasi. Bentuk-bentuk sediaan yang dapat digunakan beragam. Bentuk yang populer adalah tablet, kapsul, kaplet, suspense dan berbagai larutan sediaan farmasi.

Penggolongan obat dimaksudkan untuk peningkatan keamanan dan ketepatan penggunaan serta pengamanan distribusi. Penggolongan obat ini terdiri dari : obat bebas, obat bebas terbatas, obat wajib apotek, obat keras, psikotropika dan narkotika.

\section{E. Puskesmas}

Pusat Kesehatan Masyarakat (Puskesmas) adalah fasilitas pelayanan kesehatan yang menyelenggarakan upaya kesehatan masyarakat dan upaya kesehatan perseorangan tingkat pertama, dengan lebih mengutamakan upaya promotif dan preventif, untuk mencapai derajat kesehatan masyarakat yang setinggi-tingginya di wilayah kerjanya [4].

\section{F. Profil Puskesmas Sepatan}

Puskesmas Sepatan merupakan badan pelayanan kesehatan yang berada di alamat Jalan Raya Mauk Km 11 Kodepos 15520, Telp (021) 59372087. Memiliki visi "Puskesmas Sepatan Menuju Pelayanan Prima". Puskesmas ini dipimpin oleh Ibu dr. Elni Handayani dan memiliki beberapa sub koordinasi salah satunya yaitu sub koordinasi farmasi dengan koordinator Ibu Lisdiyanti,S.Si.,Apt yang bertugas sebagai pengelola obat di Puskesmas Sepatan.

\section{G. Metodologi Penelitian}

Metodologi penelitian adalah langkah dan prosedur yang akan dilakukan dalam pengumpulan data atau informasi guna memecahkan permasalahan dan menguji hipotesis penelitian. Metode yang digunakan dalam penelitian merupakan dasar penyusunan rancangan penelitian dan merupakan penjabaran dari metode ilmiah secara umum.

\section{H. Kerangka Metodologi Penelitian}

Kerangka metodologi penelitian menggambarkan langkah dan prosedur yang dilakukan dalam proses mengembangkan sistem dimulai dari mengidentifikasi masalah yang ada di Puskesmas Sepatan. Seperti pada Gambar 1.

\section{Jenis Penelitian}

Jenis penelitian digunakan dalam perencanaan dan pelaksanaan penelitian, penelitian ini merupakan

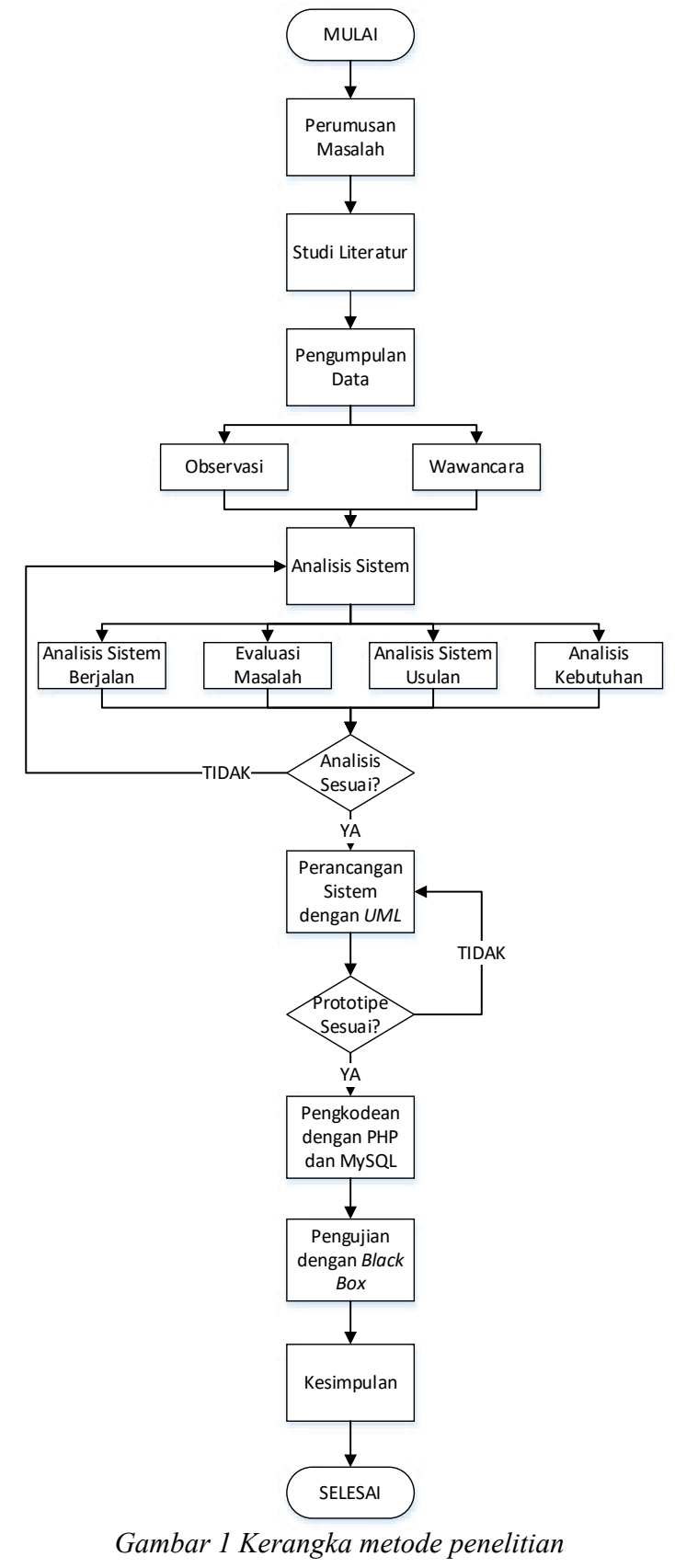

penelitian kualitatif dengan tipe action research. Penelitian Kualitatif adalah salah satu prosedur penelitian yang menghasilkan data deskriptif berupa ucapan atau tulisan dan perilaku objek yang diamati dan Action Research Ialah penelitian yang bertujuan untuk mengembangkan keterampilan-keterampilan baru, cara pendekatan baru, atau produk pengetahuan yang baru dan untuk memecahkan masalah dengan penerapan langsung di dunia aktual (lapangan).

Pada penelitian ini peneliti mengumpulkan data deskriptif dari objek penelitian dengan melakukan wawancara, observasi dan pengumpulan data dari literatur dan dokumen kerja yang ada di Puskesmas Sepatan dan selanjutnya menganalisa dan mengembangkan konsep sesuai dengan keinginan yang disampaikan oleh partisipan. 
Selanjutnya peneliti akan memecahkan permasalahan yang ada setelah melakukan pengumpulan data pada proses penelitian kualitatif dan selanjutnya melakukan pengembangan sistem dengan mengembangkan sistem informasi persediaan obat di Puskesmas Sepatan.

\section{J. Metode Pengumpulan Data}

Pada penelitian ini data primer diperoleh dengan melakukan pengamatan secara langsung (observasi) di Apotek Puskesmas Sepatan dan melakukan wawancara dengan petugas farmasi yaitu Ibu Lisdiyanti,S.Si.,Apt sedangkan data sekunder diperoleh dari dokumen-dokumen yang digunakan oleh puskesmas diantaranya SOP, buku-buku, suratsurat, catatan harian dan laporan-laporan lainnya dalam menjalankan proses bisnisnya.

\section{K. Metode Pendekatan Sistem}

Metode pendekatan sistem yang digunakan pada penelitian ini adalah metode pendekatan dengan berorientasi objek yang menggunakan OOAD (Object Oriented Analysis Design) yang digambarkan dengan Diagram UML diantaranya: Use Case Diagram, Activity Diagram dan Class Diagram [5].

Pemodelan Sistem Informasi Berorientasi Objek dengan UML yaitu berorientasi obyek atau object oriented merupakan paradigma baru dalam rekayasa perangkat lunak yang memandang sistem sebagai kumpulan obyek-obyek diskrit yang bekerja sama antara informasi atau struktur data dan prilaku (behaviour) yang mengaturnya.

\section{Metode Pengembangan Sistem}

Metode Pengembangan sistem seperti pada Gambar 2, yang digunakan pada penelitian ini adalah metode prototyping. Proses pada model prototyping yang digambarkan pada gambar model prototyping, bisa dijelaskan sebagai berikut [6]: a) Mendengarkan Pelanggan: developer dan klien bertemu dan menentukan tujuan umum, kebutuhan yang diketahui dan gambaran bagian-bagian yang akan dibutuhkan; b) Membangun dan Memperbaiki: perancangan dilakukan cepat dan rancangan mewakili semua aspek software yang diketahui, dan rancangan ini menjadi dasar pembuatan prototype; dan c) Pengujian: klien menguji dan mengevaluasi prototype yang dibuat dan digunakan untuk memperjelas kebutuhan software.

\section{Pengujian Sistem}

Pengujian sistem yang dibuat menggunakan metode black-box yang berfokus pada persyaratan

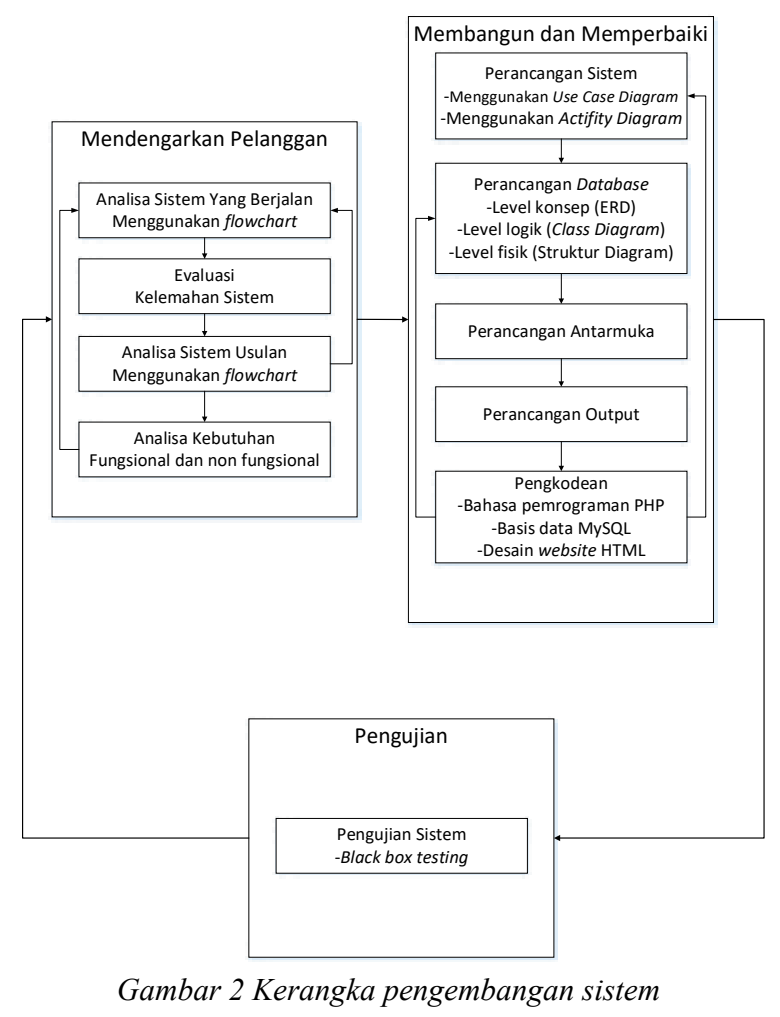

fungsional perangkat lunak. Pengujian blackbox memungkinkan perekayasa perangkat lunak mendapatkan serangkaian kondisi input yang sepenuhnya menggunakan semua persyaratan fungsional untuk suatu program.

\section{HASIL DAN PEMBAHASAN}

Pada bagian hasil dan pembahasan akan menjelaskan tentang analisa sistem, perancangan sistem dan implementasi sistem serta pengujian yang akan dilakukan.

\section{A. Analisis Sistem}

Pada proses analisis ini menggunakan Flowchart, Flowchart merupakan penggambaran secara grafik dari langkah-langkah dan urutan prosedur suatu program. Biasanya mempermudah penyelesaian masalah, khususnya yang perlu dipelajari dan dievaluasi.

\section{Analisis Sistem yang Berjalan}

Yaitu memberikan gambaran tentang sistem yang diamati yang saat ini sedang berjalan.

\section{a. Analisis Pemesanan Obat}

Pemesanan obat adalah suatu proses kegiatan pengelola obat untuk mengajukan pemesanan atau permintaan obat ke dinas kesehatan kabupaten sesuai dengan jumlah dan jenis obat yang sudah direncanakan dalam rangka pemenuhan kebutuhan obat puskesmas [7]. Dapat dilihat pada Gambar 3. 


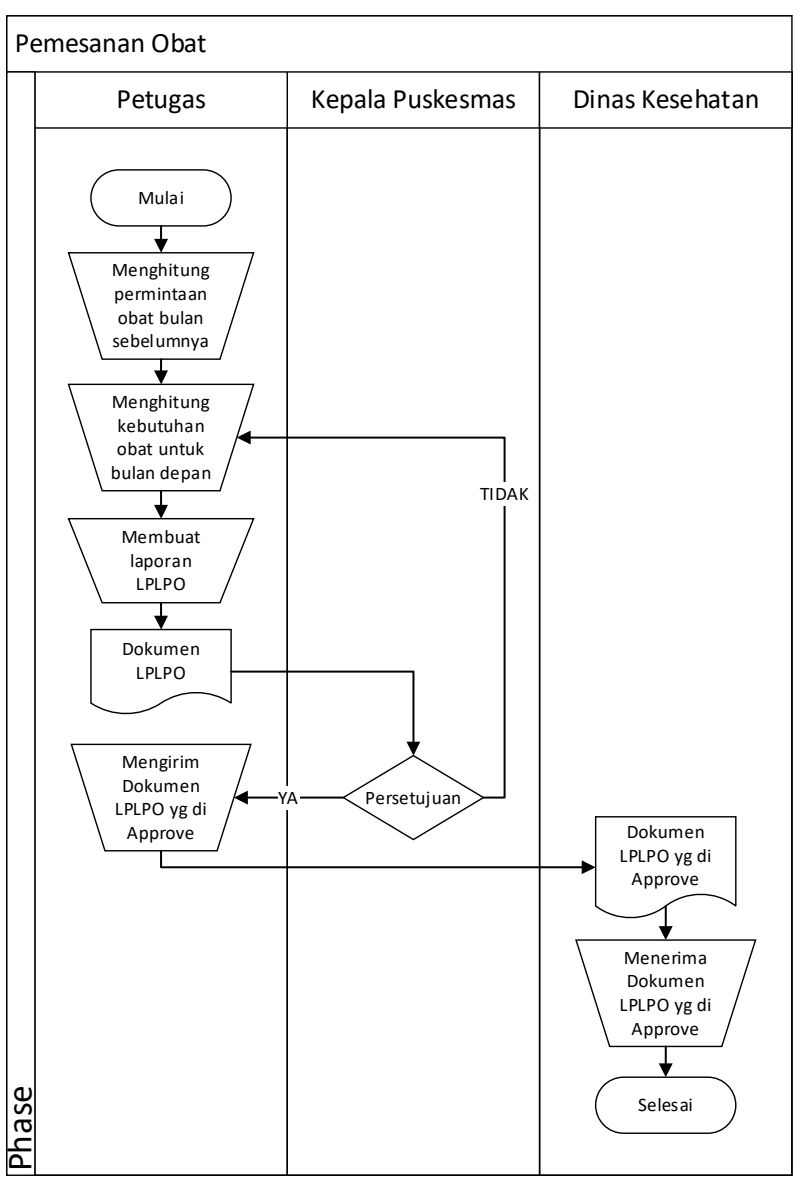

Gambar 3 Flowchart analisis pemesanan obat sistem berjalan

b. Analisis Penerimaan Obat

Penerimaan adalah suatu kegiatan dalam menerima obat-obatan yang diserahkan dari Instalasi Farmasi Dinas Kesehatan kepada petugas penerima obat yang ada di Puskesmas. seperti pada Gambar 4.

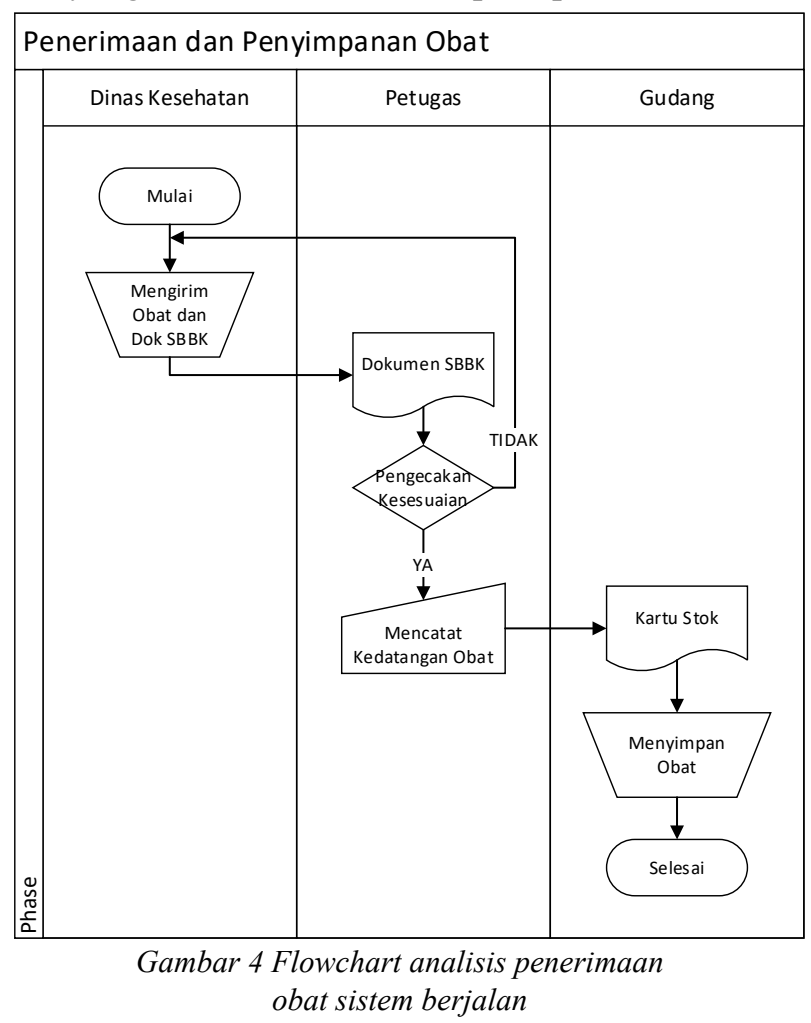

\section{c. Analisis Ubah Lokasi Obat}

Perubahan lokasi obat dilakukan berdasarkan kebutuhan persediaan obat pada Apotek puskesmas yang digunakan untuk proses pengeluaran obat, lokasi obat diubah dari lokasi gudang obat ke lokasi apotek sehingga terdapat dua stok persediaan yaitu stok gudang dan stok apotek. Dapat dilihat pada Gambar 5.

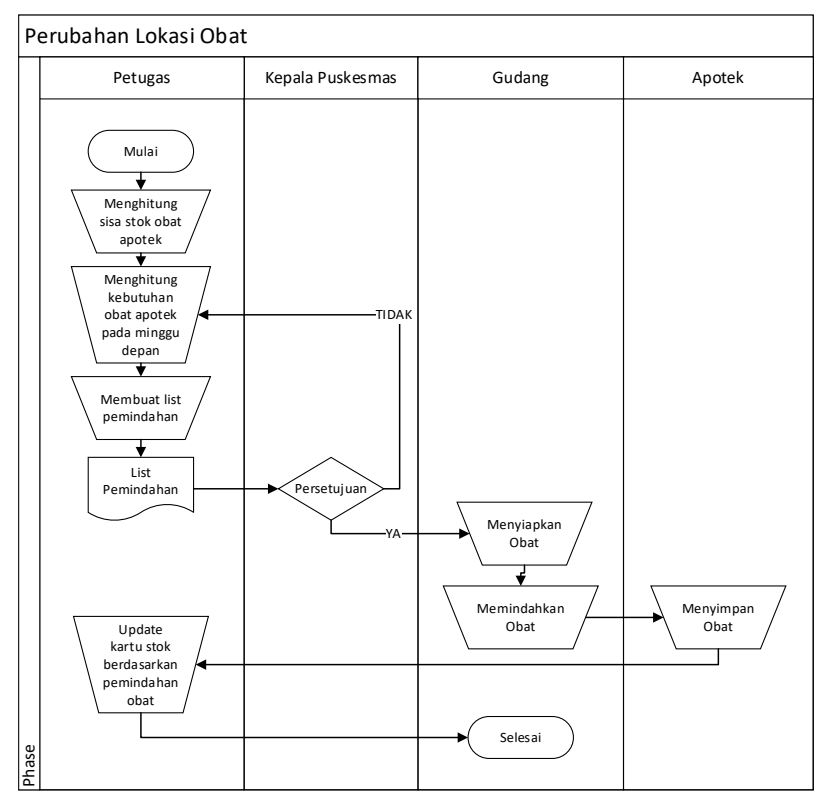

Gambar 5 Flowchart analisis perubahan lokasi obat sistem berjalan

\section{d. Analisis Pengeluaran Obat}

Pengeluaran obat dapat dilakukan berdasarkan Peresepan yang dilakukan oleh dokter kepada pasien dimana fungsi petugas farmasi menyediakan obat sesuai dengan peresepan yang telah dilakukan. Dapat dilihat pada Gambar 6.

\section{Evaluasi Sistem yang Berjalan}

Berdasarkan analisis sistem yang sedang berjalan pada pelayanan pada Puskesmas Sepatan yang masih terdapat kelemahan yaitu: a)

Pada proses pembuatan laporan LPLPO harus melakukan penghitungan pemakaian bulan sebelumnya dan kebutuhan bulan depan secara manual sehingga membutuhkan waktu yang lama; b) Pencatatan penerimaan obat manual menggunakan kartu stok; c) Pencatatan perubahan lokasi obat manual dengan menggunakan kartu stok; dan d) Pencatatan pengeluaran obat manual menggunakan registrasi obat dan kartu stok.

Dari evaluasi yang sudah dibuat dapat dibuat pemecahan masalah yaitu: Membuat sistem aplikasi yang mampu merecord dan mencetak setiap transaksi mulai dari penerimaan sampai pengeluaran dan mampu mencetak laporan LPLPO secara otomatis 


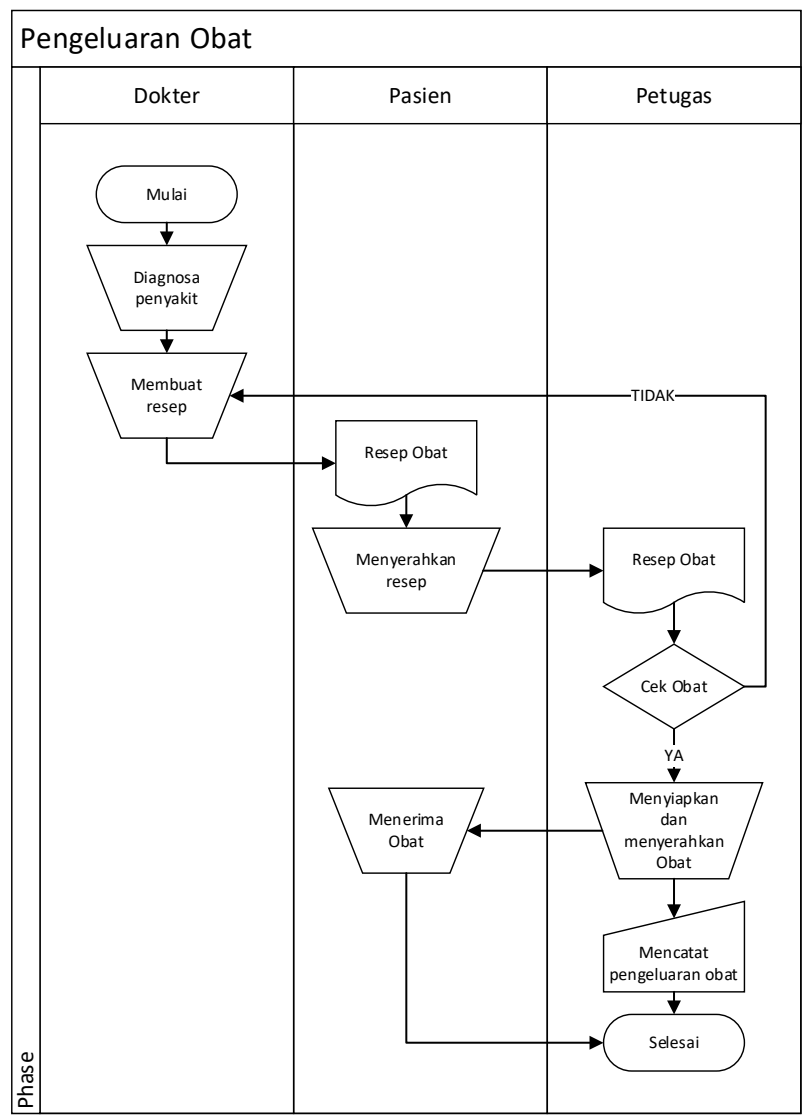

Gambar 6 Flowchart analisis pengeluaran obat sistem berjalan

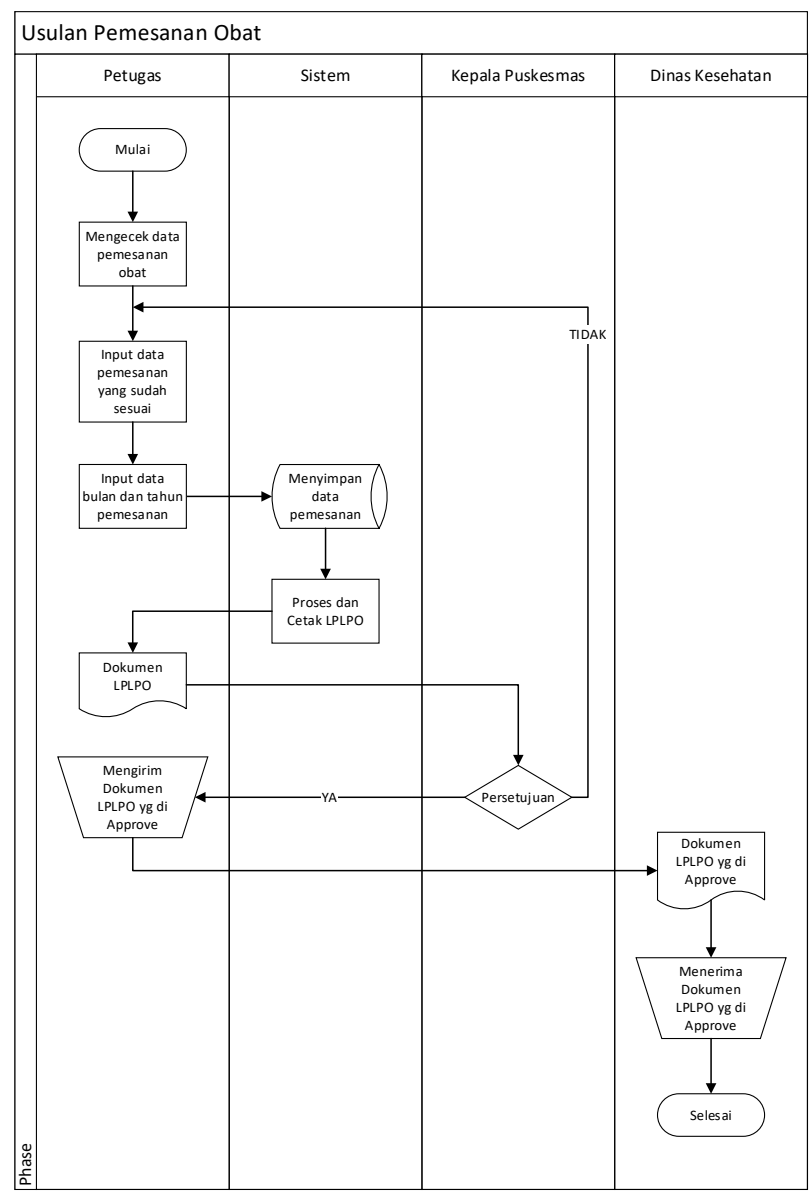

Gambar 7 Flowchart sistem usulan pemesanan obat

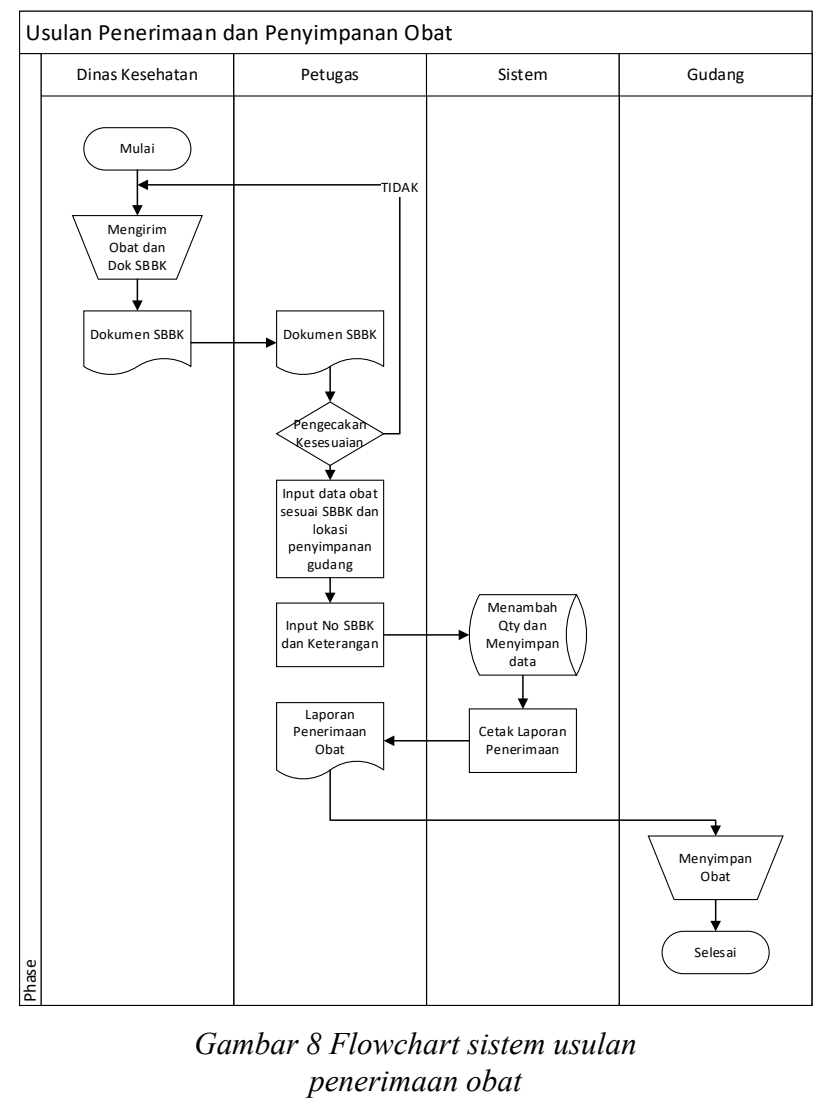

berdasarkan record transaksi yang sudah ada pada bulan sebelumnya

\section{Analisis Sistem yang Diusulkan}

Setelah melakukan analisis yang sedang berjalan maka selanjutnya akan dibahas mengenai rancangan usulan sistem yang akan dibangun.

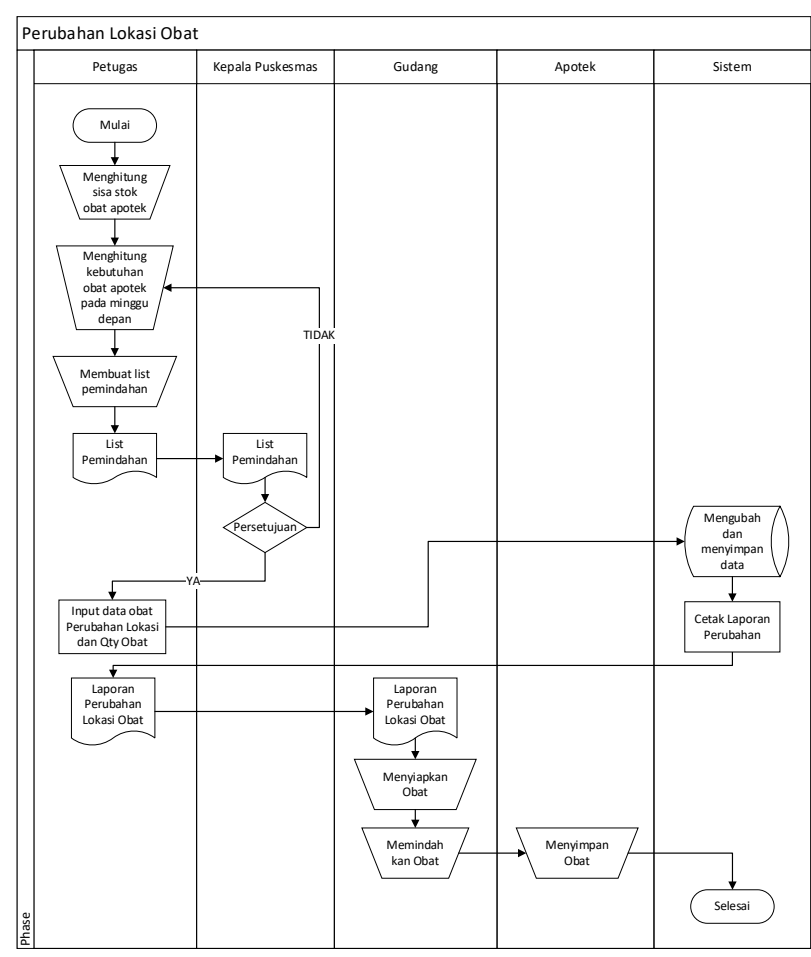

Gambar 9 Flowchart sistem usulan perubahan lokasi obat 


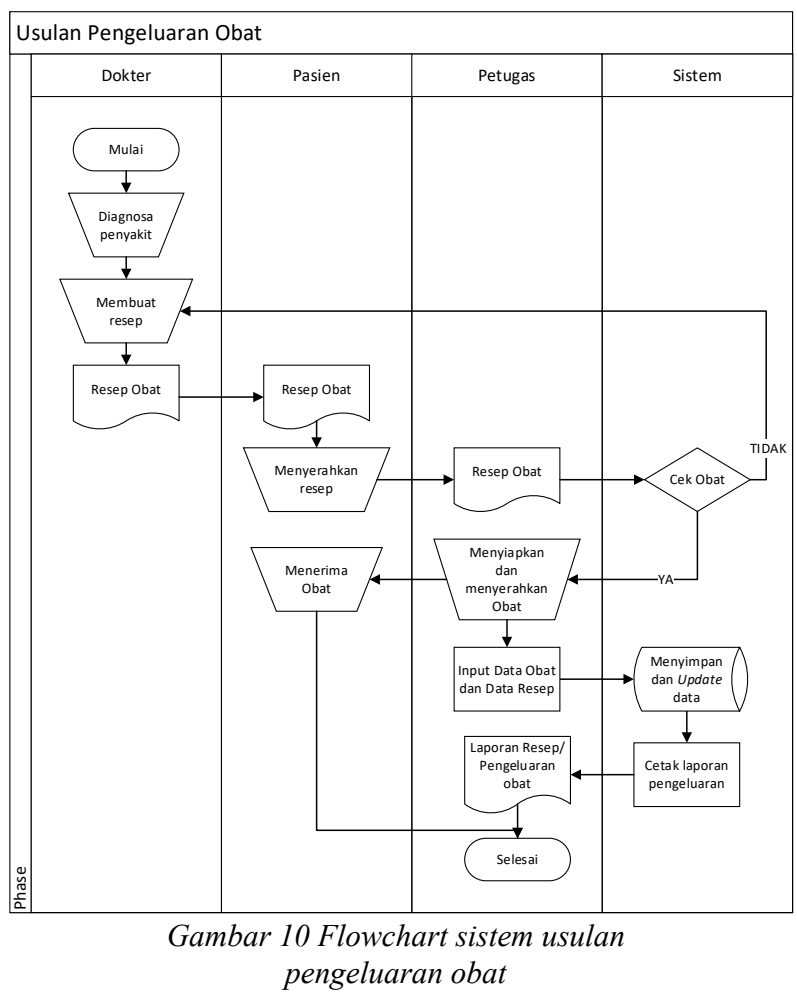

a. Usulan Sistem Pemesanan Obat

Menggambarkan langkah-langkah yang dilakukan oleh petugas farmasi Puskesmas Sepatan dalam melakukan proses pemesanan obat ke Dinas Kesehatan. Dapat dilihat pada Gambar 7.

b. Usulan Sistem Penerimaan Obat

Menggambarkan langkah-langkah yang dilakukan oleh petugas dalam melakukan proses penerimaan obat dari Dinas Kesehatan dan penyimpanan obat di gudang obat. Dapat dilihat pada Gambar 8.

\section{c. Usulan Sistem Ubah Lokasi Obat}

Menggambarkan langkah-langkah yang dilakukan oleh petugas dalam melakukan proses perubahan lokasi obat berdasarkan kebutuhan dan stok di apotek puskesmas. seperti pada Gambar 9.

d. Usulan Sistem Pengeluaran Obat

Menggambarkan langkah-langkah yang dilakukan oleh petugas farmasi Puskesmas Sepatan dalam melakukan proses pengeluaran obat berdasarkan peresepan yang dilakukan dokter kepada pasien. Dapat dilihat pada Gambar 10.

\section{Analisis Kebutuhan}

Setelah melakukan analisis sistem yang berjalan dan melakukan rancangan usulan selanjutnya menganalisis kebutuhan fungsional dan kebutuhan non fungsional yang diperlukan oleh petugas dalam menjalankan sistem usulan yang terkomputerisasi: a) Analisis Kebutuhan Fungsional: Pengolahan data Petugas; Pengolahan data Obat; Pengolahan data
Transaksi Pemesanan; Pengolahan data Transaksi Penerimaan; Pengolahan data Perubahan Lokasi; Pengolahan data Pengeluaran; dan Pengolahan Laporan; dan b) Analisis Kebutuhan Non Fungsional: Perangkat Keras; Perangkat Lunak; Keamanan; dan Tampilan yang user friendly.

\section{B. Perancangan Sistem}

Perancangan sistem merupakan tahap lanjutan dari analisis sistem dimana pada perancangan sistem digambarkan sistem yang akan dibangun sebelum dilakukan pengkodean dalam suatu bahasa pemrograman. Dalam perancangan suatu sistem tidak lepas dari hasil analisis, karena dari hasil analisis sistem baru dapat dibuat suatu rancangan sistem.

Diagram use case memperlihatkan pada kita hubungan-hubungan yang terjadi antara aktor - aktor dengan use case - use case dalam sistem. Merupakan suatu diagram yang berisi use case, actor serta relationship diantara keduanya. Use case diagram merupakan titik awal yang baik dalam memahami dan menganalisis kebutuhan sistem pada saat perancangan. Use case diagram dapat digunakan untuk menentukan kebutuhan apa saja yang diperlukan dari suatu sistem. Adapun use case diagram pada sistem informasi persediaan obat pada puskesmas sepatan yang di usulkan. Dapat dilihat pada Gambar 11.

\section{Perancangan Basis Data}

Perancangan basis data mencakup cara mengumpulkan data, format data, dokumentasi yang diperlukan, cara desain dan implementasi.

Perancangan basis data Puskesmas Sepatan bertujuan untuk menyimpan dan mengelola data pemesanan, pemasukan, persediaan dan pengeluaran obat dari apotek puskesmas.

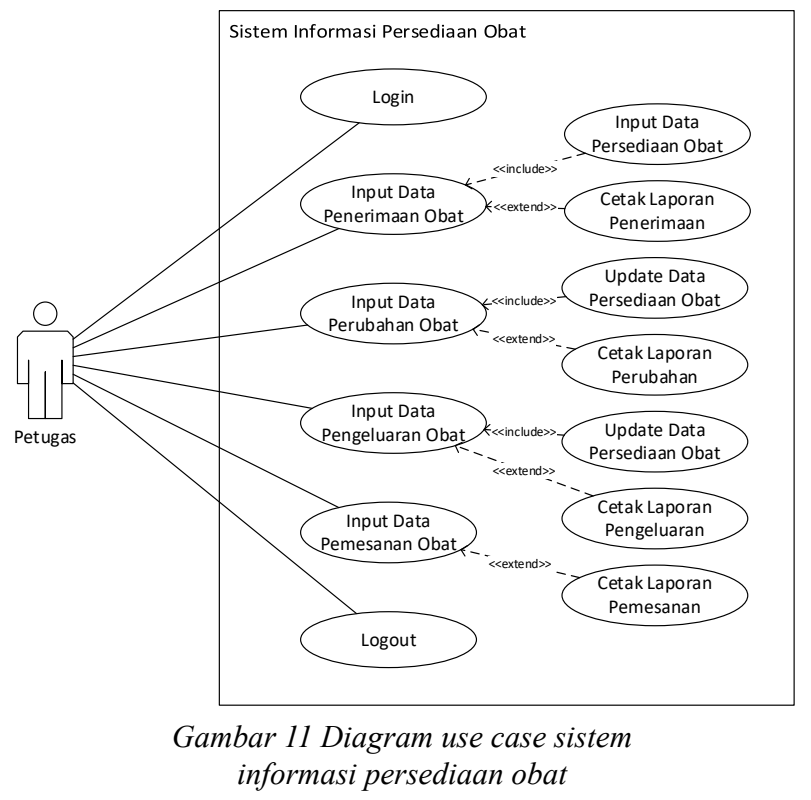




\section{Conceptual Design}

Perancangan basis data level konsep menggunakan ERD. ERD digunakan untuk memodelkan struktur data dan hubungan antar data yang ditunjukkan dengan adanya beberapa entitas yang saling dihubungkan dengan sebuah relasi, berikut gambaran ERD dari sistem yang diusulkan. Dapat dilihat pada Gambar 12.

\section{Logical Design}

Perancangan basis data level logik menggunakan class diagram. Class diagram adalah diagram yang digunakan untuk menampilkan beberapa kelas serta paket-paket yang ada dalam sistem/perangkat lunak yang akan kita kembangkan. Berikut adalah gambaran class diagram yang diusulkan. Seperti pada Gambar 13.

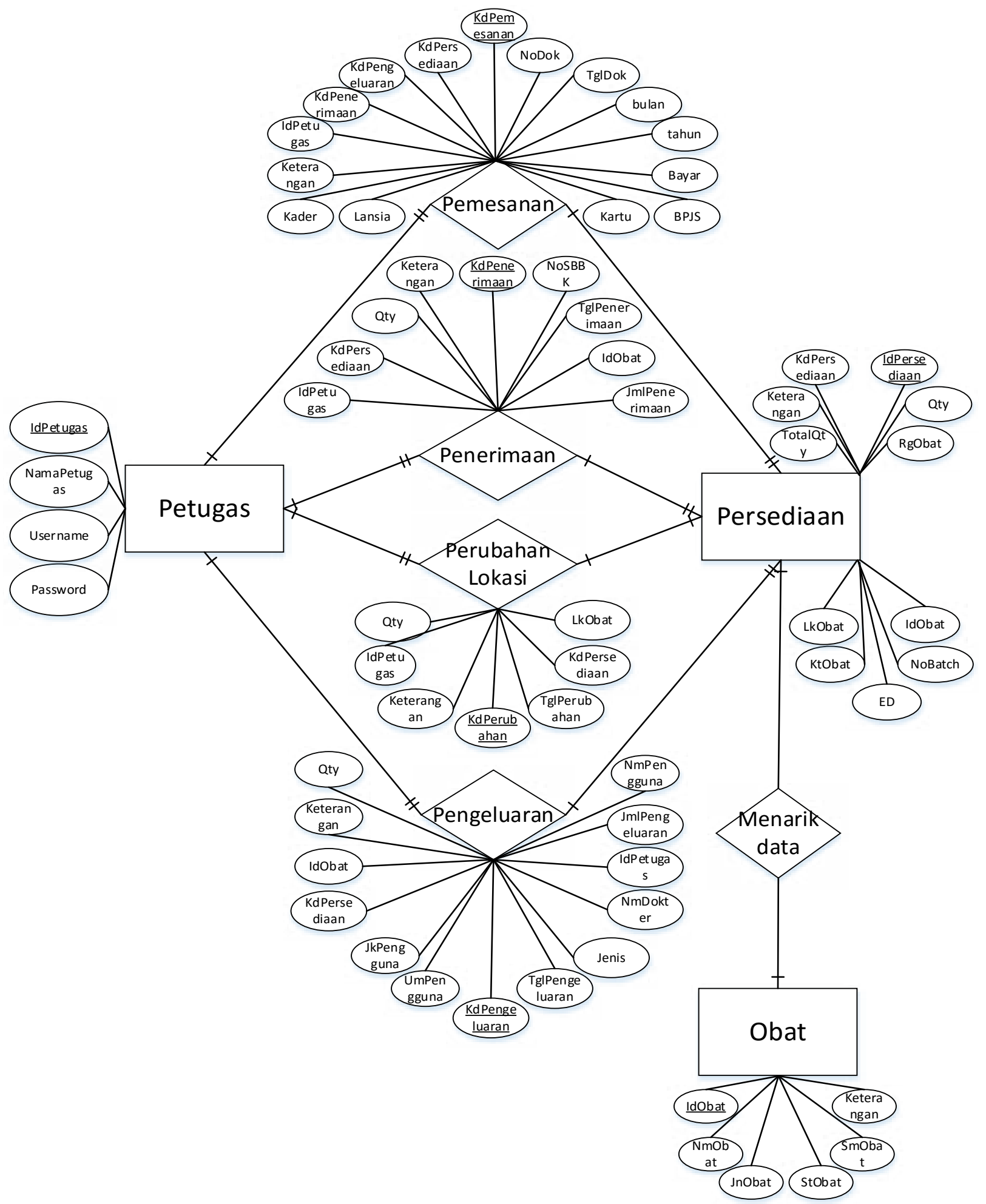

Gambar 12 ERD usulan sistem informasi persediaan obat 


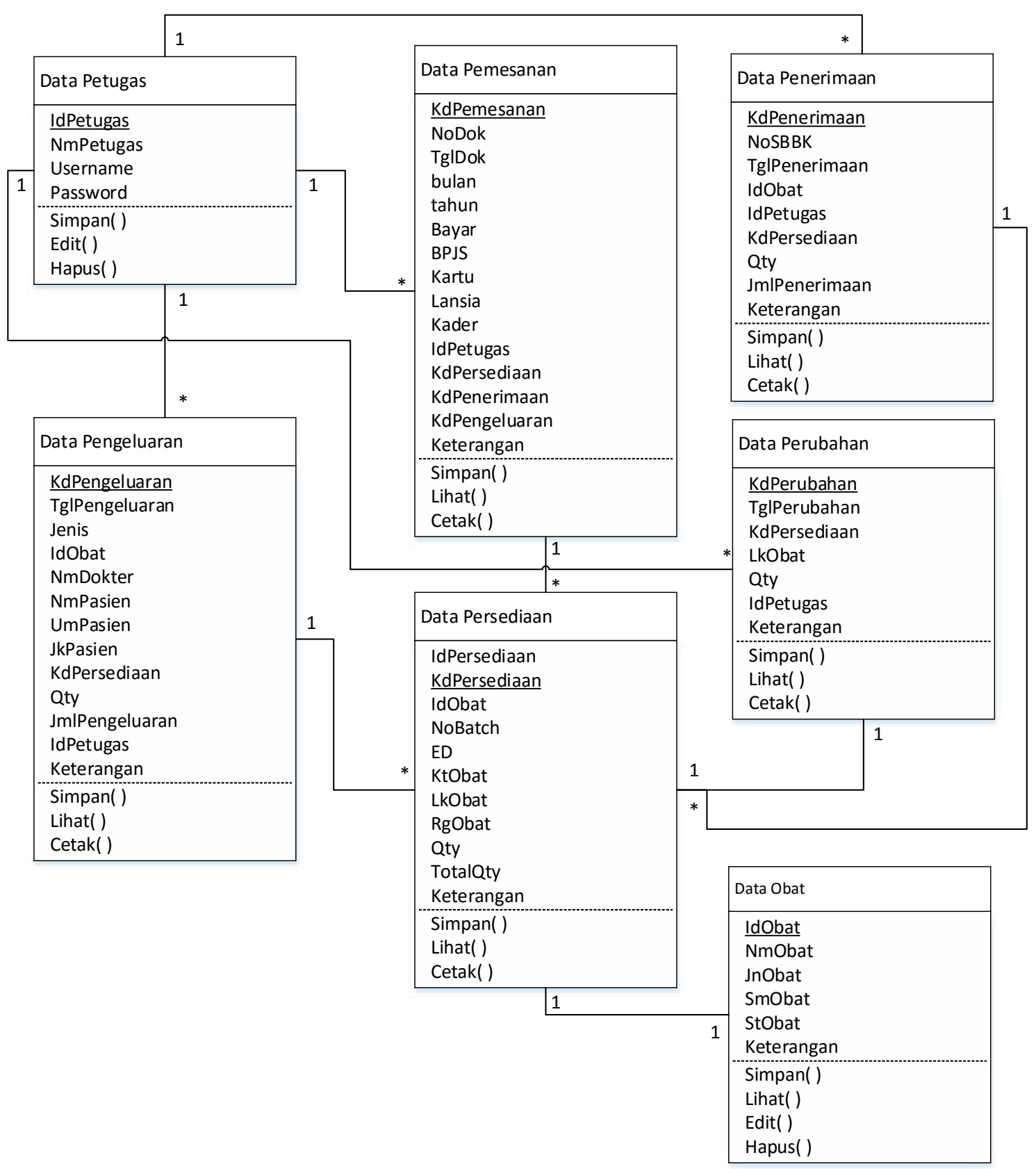

Gambar 13 Class Diagram Sistem Informasi Persediaan Obat

\section{Physical Design}

Perancangan basis data level fisik menggunakan relasi tabel. Relasi tabel menggambarkan hubungan antar class yang ditunjukkan dari primary key yang ada pada class terhadap foreign key pada class lainnya dan juga menunjukkan tipe dan panjang data. Berikut gambaran relasi tabel yang dibuat. Dapat dilihat pada Gambar 14.

\section{Kode Unik}

Rancangan sistem pengkodean ini dibuat guna mengidentifikasi suatu objek secara singkat, dengan adanya sistem pengkodean ini diharapkan dapat menklarifikasikan data, kode dapat dibentuk dari kumpulan huruf, angka dan karakter khusus. pengkodean dilakukan, Dapat dilihat pada Gambar 15, Tabel 1, Gambar 16, Tabel 2.

\section{Perancangan Antarmuka}

Perancangan antarmuka bertujuan untuk menggambarkan tampilan sistem aplikasi yang akan dibuat, berikut beberapa prototipe desain tampilan yang akan dibuat untuk Sistem Informasi Persediaan Obat Puskesmas Sepatan:

\section{Rancangan Login/Masuk}

Form Login digunakan sebagai sistem keamanan aplikasi dimana pengguna yang memiliki hak akses saja yang dapat menggunakan aplikasi ini. Hak akses diberikan kepada pengguna berupa Username dan Password dan disesuaikan dengan data petugas, hal 


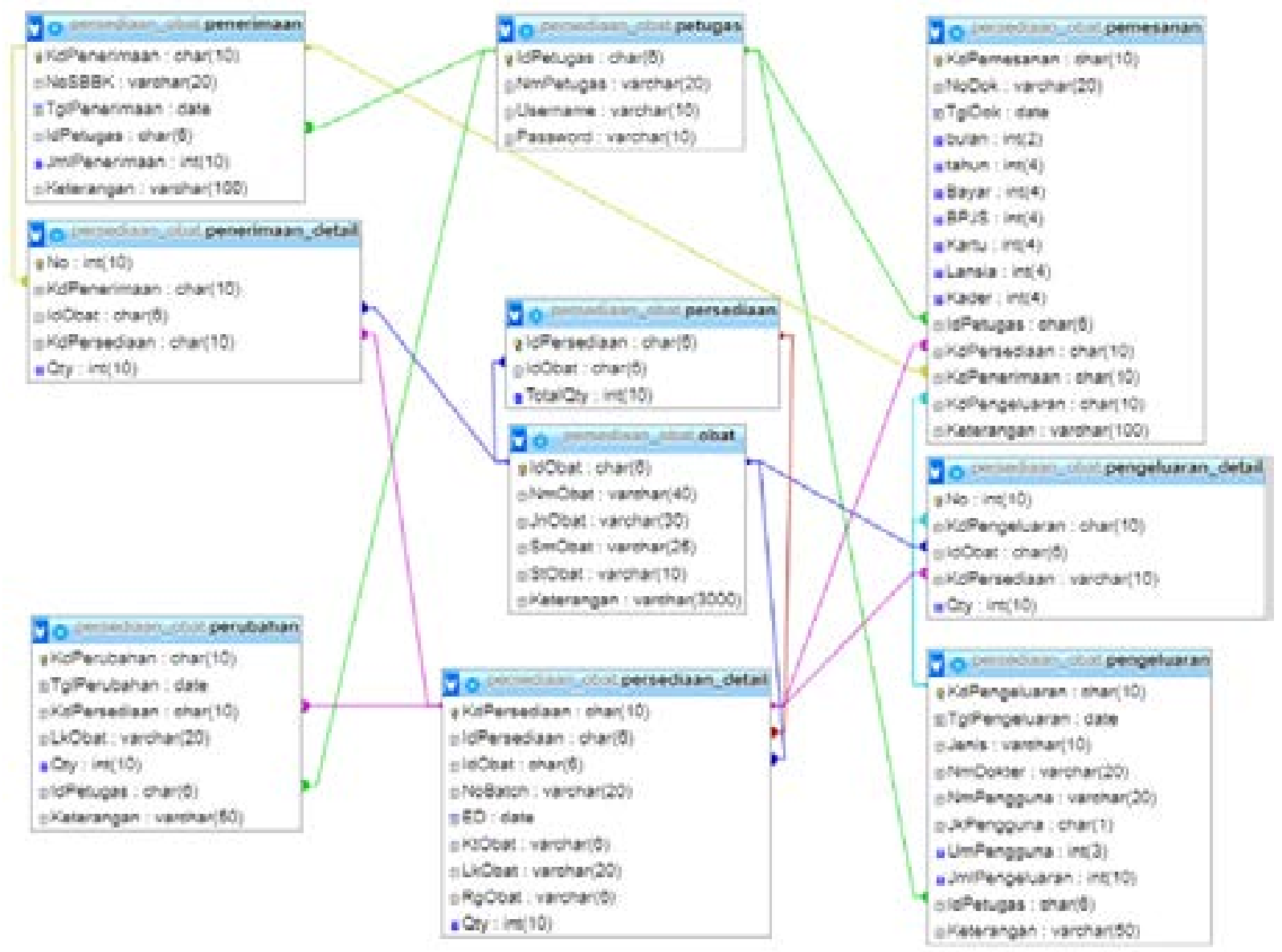

Gambar 14 Relasi tabel sistem informasi persediaan obat

\section{$\operatorname{xx} \times x \times x \times x$}

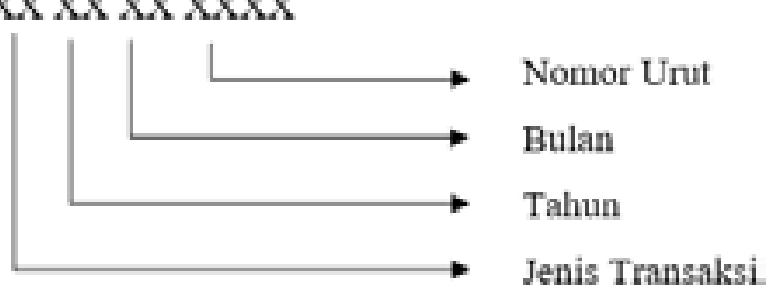

Gambar 15 Format kode unik transaksi

Tabel 1 Contoh kode unik transaksi

\begin{tabular}{|l|l|}
\hline Transaksi & Contoh \\
\hline Pemesanan & TP17070001 \\
\hline Penerimaan & TM17070002 \\
\hline Perubahan Lokasi & SA17070003 \\
\hline Pengeluaran & TK17070004 \\
\hline
\end{tabular}

ini dilakukan karena hak akses yang digunakan dapat berfungsi sebagai session sehingga dapat merekam histori penggunaan transaksi yang dilakukan oleh petugas, berikut antarmuka form login yang dibuat. Dapat dilihat pada Gambar 17.

\section{Rancangan Dashboard}

Dashboard adalah halaman awal yang ditampilkan setelah proses login berhasil dilakukan, pada halaman ini terdapat beberapa menu dengan sub-sub menu yang ada didalamnya dan setiap

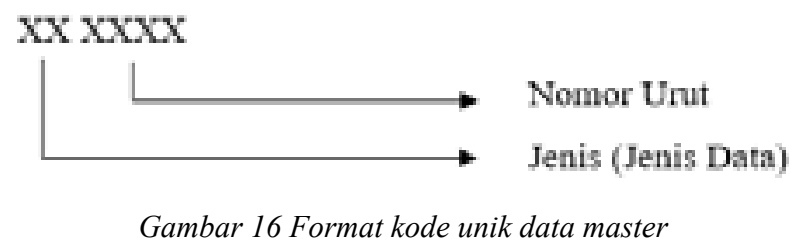

Tabel 2 Contoh kode unik data master

\begin{tabular}{|l|l|}
\hline Data Master & Contoh \\
\hline Kode Obat & OB0001 \\
\hline Kode Stok & SO0001 \\
\hline
\end{tabular}

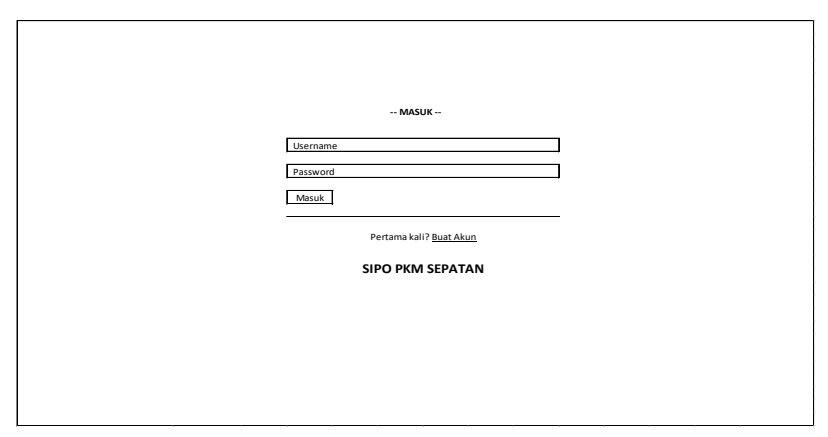

Gambar 17 Rancangan antarmuka login

menu memiliki fungsi sesuai kebutuhan yang akan dikembangkan, pada bagian tengah akan dibuat grafik yang berisikan data berdasarkan pengolahan data dari setiap transaksi yang dilakukan pada bulan berjalan. Berikut tampilan rancangan antarmuka dari 
halaman Dashboard yang akan dibuat. Dapat dilihat pada Gambar 18.

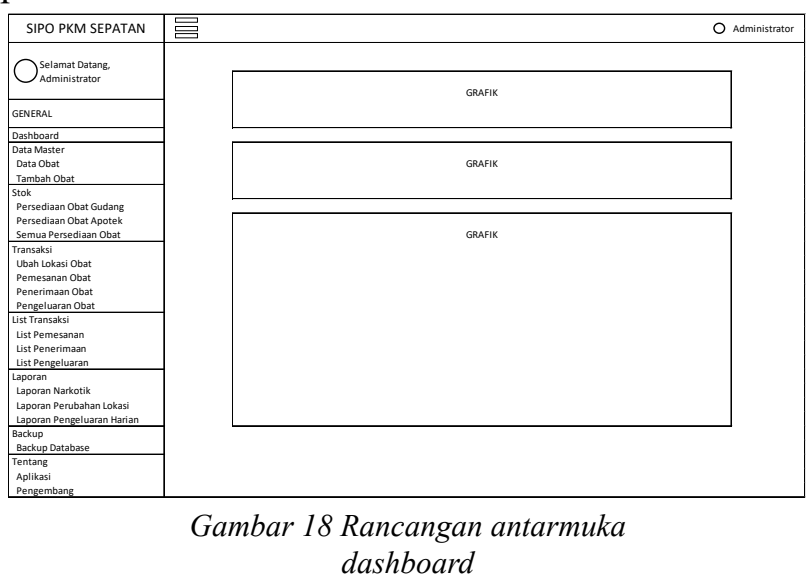

\section{Rancangan Tambah Obat}

Form Tambah Obat digunakan untuk menambah data master obat, terdapat 3 form input diantaranya ID Obat yang otomatis terisi berdasarkan urutan penyimpanan, Nama Obat sesuai dengan data standar dari Dinas Kesehatan dan Keterangan, 3 form select diantaranya Jenis Obat yaitu penggolongan obat berdasarkan mekanisme kerja obat, Suhu Penyimpanan yaitu suhu dalam derajat celcius yang diperbolehkan dalam proses penyimpanan obat dan Satuan Obat yaitu jenis sediaan yang dibuat oleh perusahaan pembuat obat dan terdapat tiga button input yaitu Batal, Reset dan Simpan. Berikut tampilan rancangan antarmuka dari form tambah obat yang akan dibuat. Dapat dilihat pada Gambar 19.

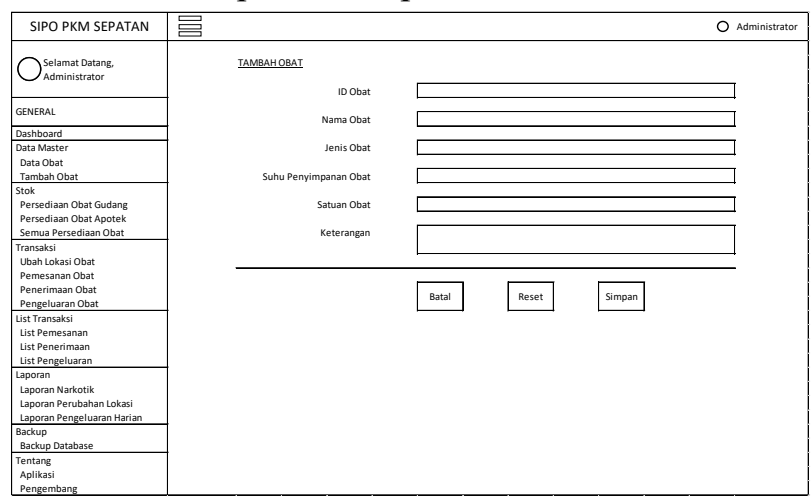

Gambar 19 Rancangan antarmuka tambah obat

\section{Rancangan Penerimaan}

Form Penerimaan digunakan untuk melakukan transaksi penerimaan obat berdasarkan dokumen dan obat yang dikirimkan oleh Dinas Kesehatan. Terdapat 2 readonly form input yaitu Kode Penerimaan yang otomatis terisi berdasarkan penomoran kode unik transaksi penerimaan dan ID Petugas berdasarkan session yang dilakukan oleh user petugas, 2 form select date yaitu Tanggal Penerimaan dan Expire
Date, 6 form input yaitu Nama Obat, Nomor Batch, Lokasi, Jumlah, No SBBK dan Keterangan, 1 select button yaitu pada Kategori Obat, 1 form table yaitu list data penerimaan obat sementara yang tersimpan di penyangga sebelum proses transaksi penerimaan disimpan dan terdapat 3 button input yaitu Batal, Reset dan Simpan. Berikut tampilan rancangan antarmuka dari form transaksi penerimaan yang akan dibuat. Dapat dilihat pada Gambar 20.

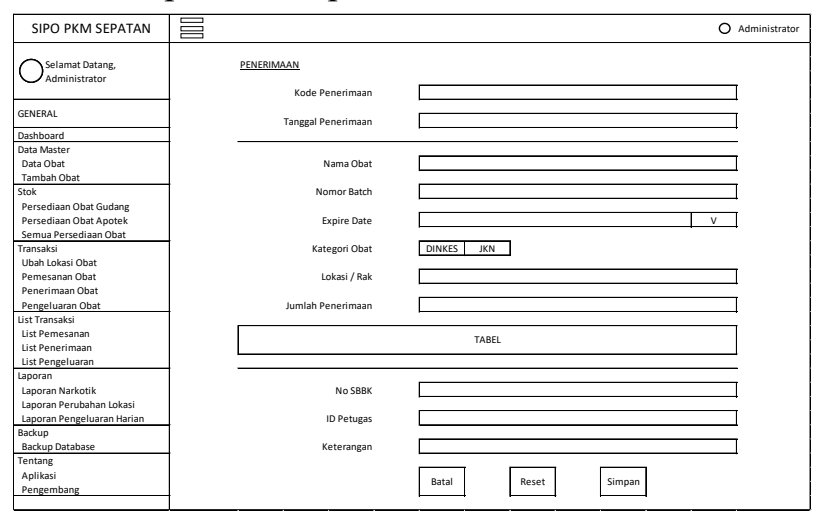

Gambar 20 Rancangan antarmuka penerimaan

\section{Rancangan Pengeluaran}

Form Pengeluaran digunakan untuk melakukan transaksi pengeluaran obat berdasarkan resep yang diserahkan pasien berdasarkan peresepan dan diagnosa yang dilakukan oleh dokter. Terdapat 2 readonly form input yaitu Kode Pengeluaran yang otomatis terisi berdasarkan penomoran kode unik transaksi pengeluaran dan ID Petugas berdasarkan session yang dilakukan oleh user petugas, 1 form select date yaitu Tanggal Pengeluaran, 6 form input yaitu Nama Obat, Jumlah, Pemesan/Dokter, Nama Pasien, Umur Pasien dan Keterangan, 2 select button yaitu pada Jenis Pengeluaran dan Jenis Kelamin Pasien, 1 form table yaitu list data pengeluaran obat sementara yang tersimpan di penyangga sebelum proses transaksi pengeluaran disimpan dan terdapat 3 button input yaitu Batal, Reset dan Simpan. Berikut tampilan rancangan antarmuka dari form transaksi pengeluaran yang akan dibuat. Dapat dilihat pada Gambar 21.

\section{Rancangan Pemesanan}

Form Pemesanan digunakan untuk melakukan transaksi pemesanan obat dan berfungsi untuk menghasilkan dokumen LPLPO yang akan dikirim ke Dinas Kesehatan. Terdapat 2 readonly form input yaitu Kode Pemesanan yang otomatis terisi berdasarkan penomoran kode unik transaksi pemesanan dan ID Petugas berdasarkan session yang dilakukan oleh 


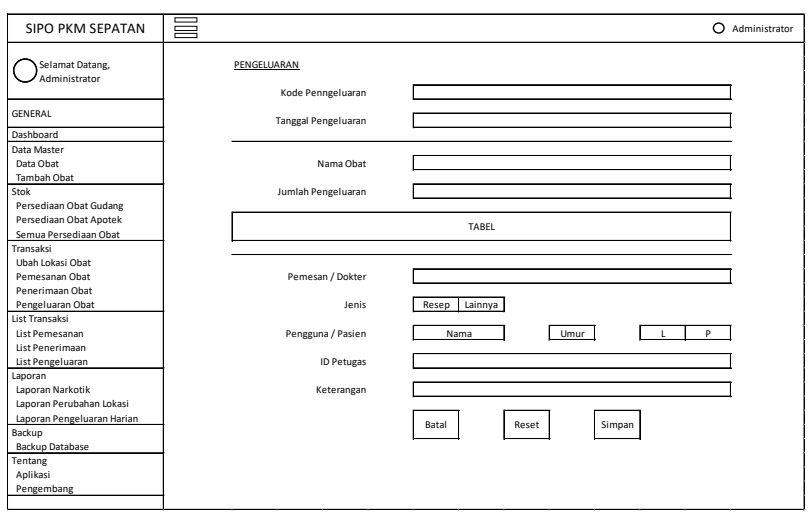

Gambar 21 Rancangan antarmuka pengeluaran

user petugas, 1 form select yaitu Bulan, 8 form input yaitu No Dokumen, Tahun, Jumlah Kunjungan dengan 5 form input dan Keterangan dan terdapat 3 button input yaitu Batal, Reset dan Simpan. Berikut tampilan rancangan antarmuka dari form transaksi pemesanan yang akan dibuat. Dapat dilihat pada Gambar 22.

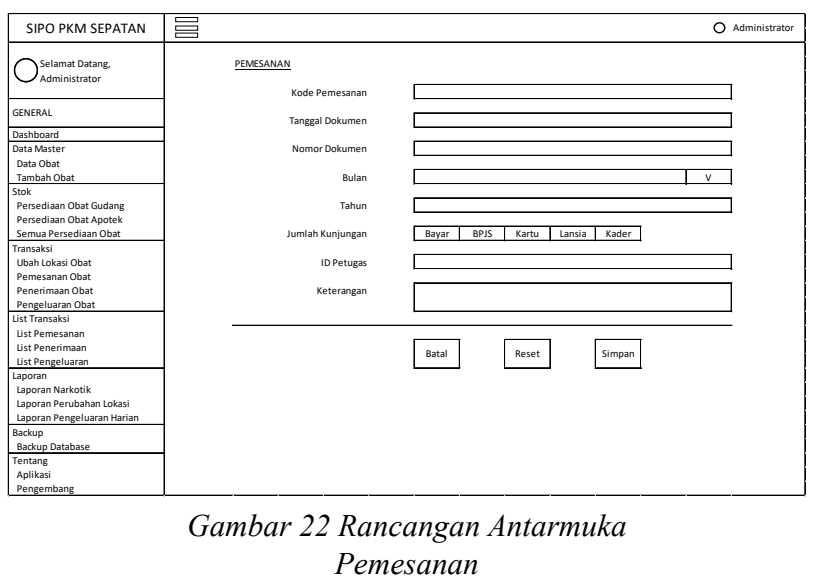

\section{Rancangan Perubahan Lokasi}

Form Perubahan Lokasi digunakan untuk melakukan transaksi perubahan lokasi obat dari gudang ke apotek berdasarkan list kebutuhan yang telah dibuat. Terdapat 4 readonly form input yaitu Kode Perubahan Lokasi yang otomatis terisi berdasarkan penomoran kode unik stok apotek, Tanggal Perubahan, Lokasi Apotek dan ID Petugas berdasarkan session yang dilakukan oleh user petugas, 4 form input yaitu Nama Obat, Lokasi Rak, Jumlah dan Keterangan dan terdapat 3 button input yaitu Batal, Reset dan Simpan. Berikut tampilan rancangan antarmuka dari form transaksi perubahan lokasi yang akan dibuat. Dapat dilihat pada Gambar 23.

\section{E. Perancangan Output}

Perancangan Desain Output bertujuan untuk menggambarkan tampilan laporan-laporan yang akan dibuat dan dicetak, berikut beberapa prototipe desain

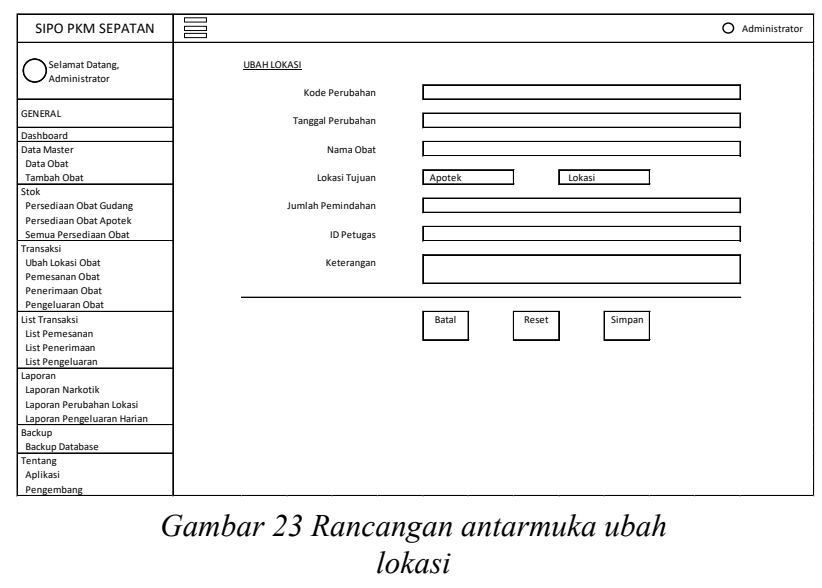

laporan yang akan dibuat untuk Sistem Informasi Persediaan Obat:

\section{Rancangan Laporan Penerimaan}

Rancangan laporan penerimaan dibuat sebagai output dari transaksi penerimaan yang dilakukan oleh petugas berdasarkan kedatangan obat dan dokumen SBBK yang dikirim oleh dinas kesehatan, laporan ini digunakan sebagai arsip dan bukti penerimaan obat. Data laporan penerimaan diambil dari tabel penerimaan, tabel persediaan_detail dan tabel obat yang saling berelasi. Dapat dilihat pada Gambar 24.

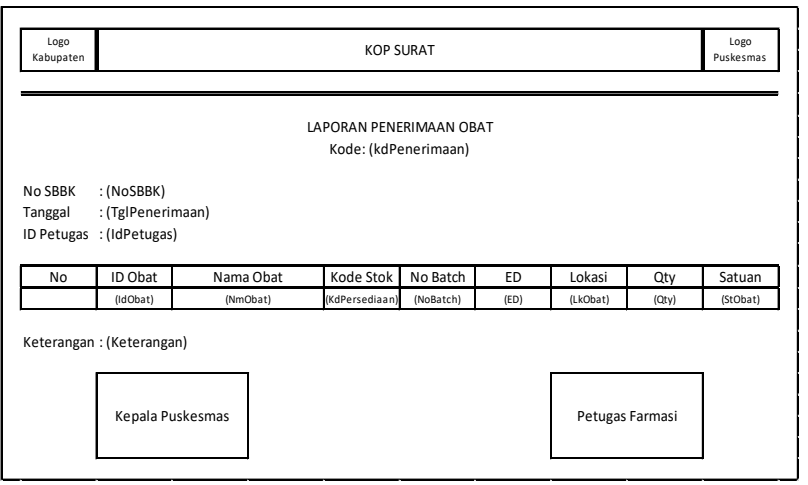

Gambar 24 Rancangan output penerimaan

\section{Rancangan Laporan Pengeluaran}

Rancangan laporan pengeluaran dibuat sebagai output dari transaksi pengeluaran yang dilakukan oleh petugas berdasarkan resep dokter yang diserahkan oleh pasien, laporan ini digunakan sebagai arsip dan bukti pengeluaran obat. Data laporan pengeluaran diambil dari tabel pengeluaran, tabel persediaan detail dan tabel obat yang saling berelasi. Dapat dilihat pada Gambar 25.

\section{Rancangan Laporan Pengeluaran Harian}

Rancangan laporan pengeluaran harian dibuat sebagai output dari total transaksi pengeluaran yang dilakukan oleh petugas selama satu hari berdasarkan tanggal pelaporan, laporan ini digunakan sebagai 


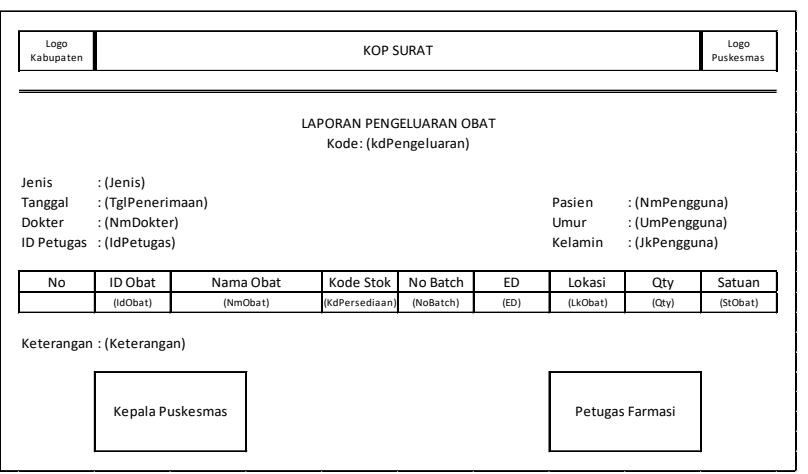

Gambar 25 Rancangan output pengeluaran

arsip dan bukti total pengeluaran obat harian. Data laporan pengeluaran harian diproses dengan menjumlahkan qty obat berdasarkan ID Obat yang sama, data ini diperoleh dari tabel pengeluaran, tabel persediaan_detail dan tabel obat yang saling berelasi. Dapat dilihat pada Gambar 26.

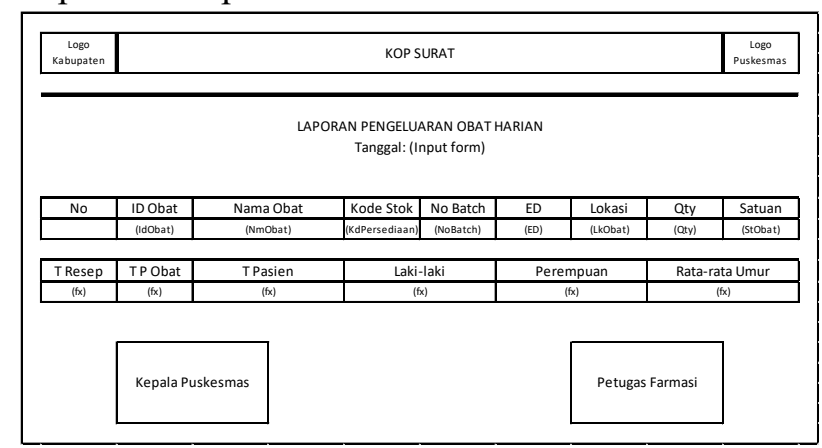

Gambar 26 Rancangan output pengeluaran harian

\section{Rancangan Laporan Ubah Lokasi Obat}

Rancangan laporan perubahan lokasi obat dibuat sebagai output dari total transaksi perubahan lokasi yang dilakukan oleh petugas selama satu hari berdasarkan tanggal pelaporan, laporan ini digunakan sebagai arsip dan bukti total perubahan lokasi obat. Data laporan perubahan lokasi diperoleh dari tabel perubahan, tabel persediaan_detail dan tabel obat yang saling berelasi. Dapat dilihat pada Gambar 27.

\section{Rancangan Laporan Pemesanan}

Rancangan laporan pemesanan dibuat sebagai output dari transaksi pemesanan yang dilakukan

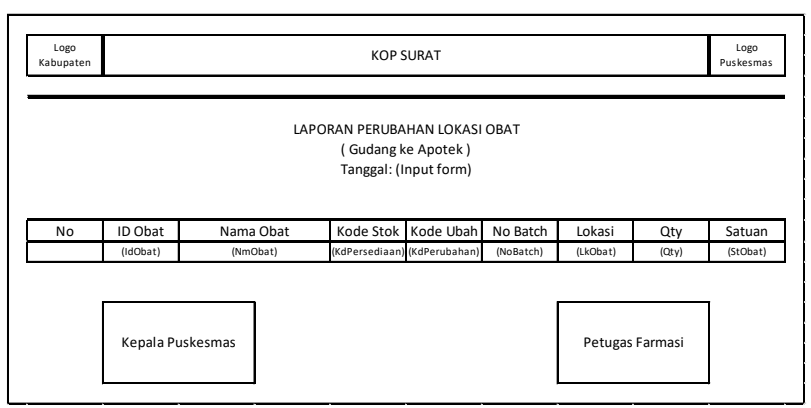

Gambar 27 Rancangan output ubah lokasi oleh petugas, laporan ini digunakan sebagai dokumen pemesanan obat yang dikirim kepada dinas kesehatan. Data laporan pemesanan diperoleh dari tabel pemesanan, tabel persediaan_detail, tabel penerimaan, tabel pengeluaran dan tabel obat yang saling berelasi. Dapat dilihat pada Gambar 28.

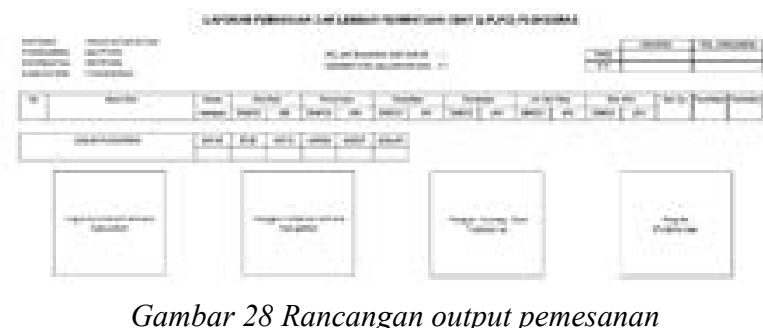

\section{Rancangan Laporan Narlotika}

Rancangan laporan narkotik dibuat sebagai output dari setiap transaksi yang dilakukan oleh petugas berdasarkan penggolongan obat yaitu narkotika dan psikotropika, laporan ini digunakan sebagai dokumen pengawasan dan pengendalian obat yang diminta oleh dinas kesehatan. Data laporan narkotik diperoleh dari tabel persediaan detail, tabel penerimaan, tabel pengeluaran dan tabel obat yang saling berelasi dan di filter berdasarkan jenis obat narkotika dan psikotropika. Dapat dilihat pada Gambar 29.

\section{F. Pengkodean}

Pengkodean dilakukan dengan menggunakan bahasa pemrograman PHP dan HTML dengan database MySQL, berikut beberapa contoh pengkodean yang telah dibuat:

\section{Pengkodean Penerimaan}

Pada pengkodean penerimaan terdapat 2 fungsi yang dijalankan yaitu insert dan update. Fungsi insert digunakan untuk menambahkan data pada tabel penerimaan, tabel penerimaan_detail dan tabel persediaan_detail dan fungsi update digunakan untuk memperbarui data pada tabel persediaan.

\section{Pengkodean Perubahan Lokasi}

Pada pengkodean perubahan lokasi terdapat 2

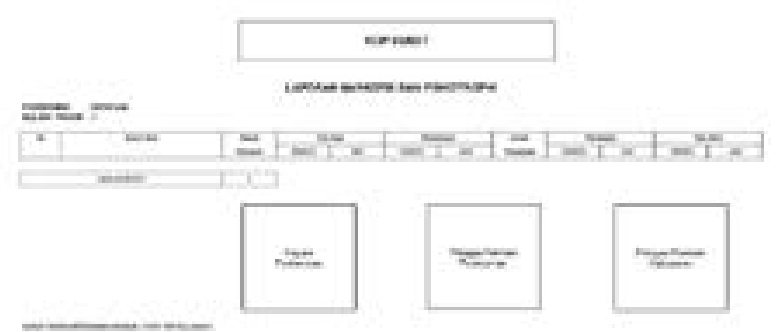

Gambar 29 Rancangan output laporan narkotika 
fungsi yang dijalankan yaitu insert dan update. Fungsi insert digunakan untuk menambahkan data pada tabel perubahan, dan tabel persediaan_detail dan fungsi update digunakan untuk memperbarui data pada tabel persediaan_detail.

\section{Pengkodean Pengeluaran}

Pada pengkodean pengeluaran terdapat 2 fungsi yang dijalankan yaitu insert dan update. Fungsi insert digunakan untuk menambahkan data pada tabel pengeluaran, tabel pengeluaran_detail dan fungsi update digunakan untuk memperbarui data pada tabel persediaan dan tabel persediaan_detail.

\section{Pengkodean Pemesanan}

Pada pengkodean pemesanan terdapat 2 fungsi yang dijalankan yaitu insert dan query. Fungsi insert digunakan untuk menambahkan data pada tabel pemesanan, dan fungsi query digunakan untuk mengambil dan memproses data, fungsi ini dijalankan dengan mengolah data dari tabel penerimaan, tabel penerimaan_detail, tabel persediaan, tabel persediaan detail, tabel pengeluaran, tabel pengeluaran_detail dan tabel obat.

\section{G. Implementasi Kebutuhan}

Untuk mendukung sistem yang dikembangkan berjalan dengan optimal dibutuhkan perangkat keras dan perangkat lunak dengan spesifikasi yang baik. Adapun perangkat yang digunakan sebagai berikut:

\section{Implementasi Perangkat Keras}

Perangkat keras yang digunakan untuk mendukung pembuatan dan menjalankan program aplikasi Sistem Informasi Persediaan Obat diperlukan satu (unit) Komputer PC dengan spesifikasi sebagai berikut: a) Processor Intel Pentium dengan kecepatan $2.2 \mathrm{GHz}$; b) Harddisk $320 \mathrm{~GB}$; c) RAM 2 GB; d) VGA 2 GB; e) 1 (unit) Mouse, Keyboard dan Monitor.

\section{Implementasi Perangkat Lunak}

Perangkat lunak yang digunakan untuk mendukung pembuatan dan menjalankan program aplikasi Sistem Informasi Persediaan Obat sebagai berikut: a) Sistem Operasi Windows 7 Professional; b) Browser Google Chrome Version 59.0.3071.115 (Official Build); c) XAMPP 5.6.24; d) Foxit Reader 8.0.2.

\section{Rancangan Arsitektur Aplikasi}

Arsitektur aplikasi menspesifikasikan teknologi yang akan digunakan untuk mengimplementasikan sistem yang akan dibuat yaitu Sistem Informasi Persediaan Obat, arsitektur ini menggambarkan bagaimana komponen-komponen yang ada saling berinteraksi dan berkomunikasi. Dapat dilihat pada Gambar 30.

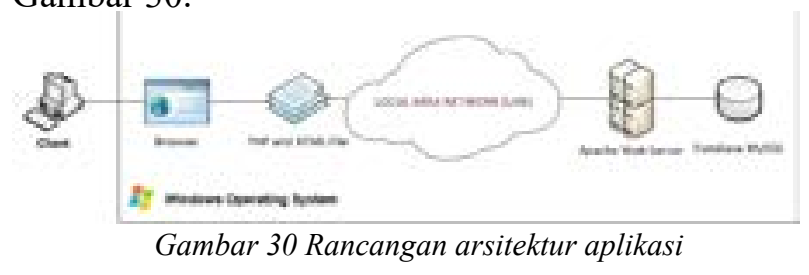

\section{H. Struktur Navigasi Implementasi}

Struktur navigasi menggambarkan alur implementasi sistem informasi persediaan obat yang dimulai dari proses instalasi program pendukung dan penggunaannya dan dilanjutkan dengan penggunaan sistem informasi persediaan obat yang dimulai dengan proses login, pemanfaatan menu berdasarkan fungsinya hingga proses logout. Berikut alur struktur navigasi implementasi yang dibuat. Dapat dilihat pada Gambar 31.

\section{Implementasi Instalasi dan Penggunaan Perangkat Lunak}

Sebelum menggunakan sistem yang sudah dikembangkan, langkah pertama yang harus dilakukan adalah melakukan instalasi XAMPP 5.6.24

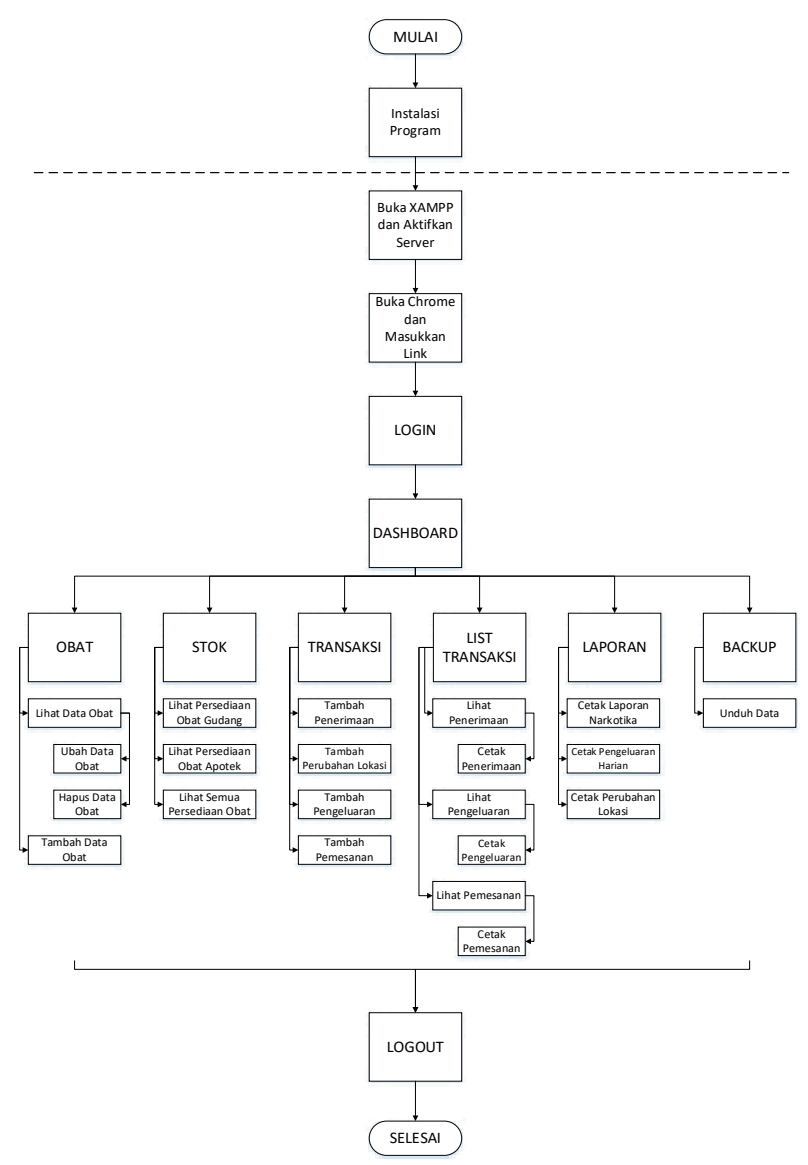

Gambar 31 Struktur Navigasi Implementasi 
pada PC yang menggunakan sistem operasi Microsoft Windows 7.

1. Klik dua kali pada icon. seperti pada Gambar 32.

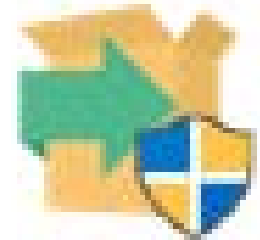

Gambar 32 Icon installer $X A M P P$

2. Lalu Pilih install dan akan muncul proses instalasi. Dapat dilihat pada Gambar 33.

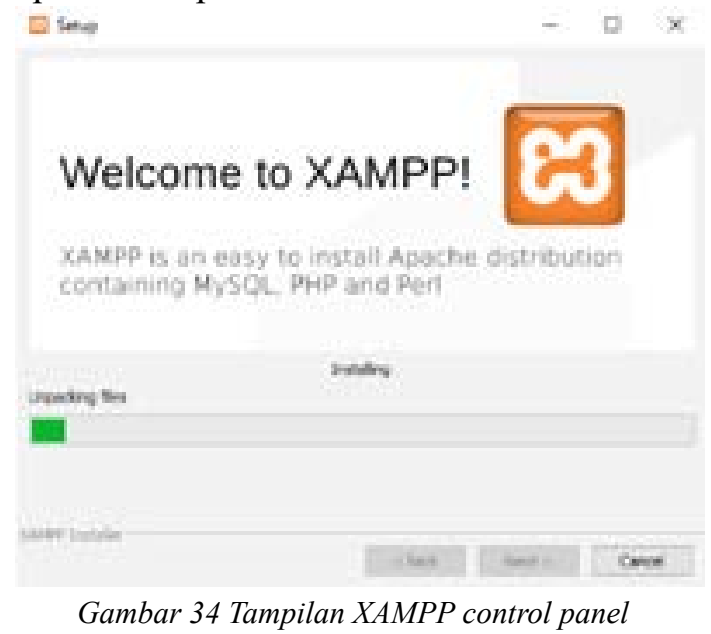

3. Setelah proses instalasi selesai, buka program dengan klik XAMPP control panel yang ada pada menu start di Windows. Seperti pada Gambar 34.

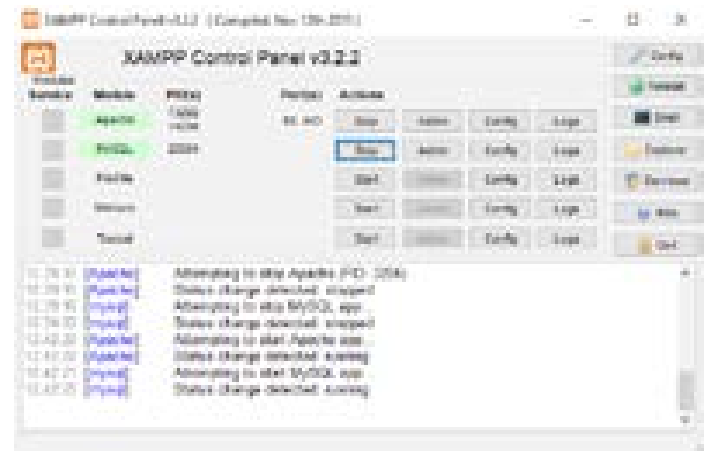

Gambar 34 Tampilan XAMPP control panel

4. Klik Start pada Apache dan MySQL hingga berubah. Dapat dilihat pada Gambar 35.

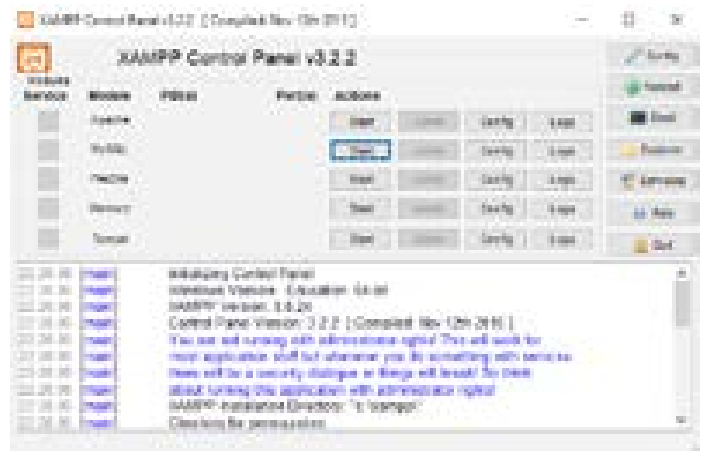

Gambar 35 Tampilan XAMPP setelah apache dan mysql running
5. Setelah XAMPP berjalan, selanjutnya jalakan browser Google Chrome. Dan ketikan pada Address Bar dengan mengetikan http://localhost/obat/ production/ lalu tekan enter dan kemudian akan tampil halaman login, Selanjutnya petugas dapat menggunakan sistem yang sudah dikembangkan. Dapat dilihat pada Gambar 36.

\section{Gambar 36 Tampilan Pada Web Browser} Google Chrome

\section{J. Implementasi Antarmuka dan Penggunaan Sistem}

Implementasi antarmuka dilakukan dengan membuat antarmuka pada masing-masing form. Setiap halaman form yang dibuat akan dibentuk sebuah file yang berekstensi php. File-file tersebut selanjutnya dapat diakses dan akan menjadi penghubung antara pengguna dengan sistem. Halaman ini hanya dapat diakses oleh Petugas karena telah ditentukan username dan password-nya.

\section{Halaman Login}

Halaman ini muncul dengan mengakses alamat http://localhost/obat/production/ yang berfungsi sebagai keamanan sistem dan untuk mengakses menu-menu yang lain. Terdapat 2 field yang harus diisi dengan data yang sudah dibuat dan diberikan hak akses. Dapat dilihat pada Gambar 37.

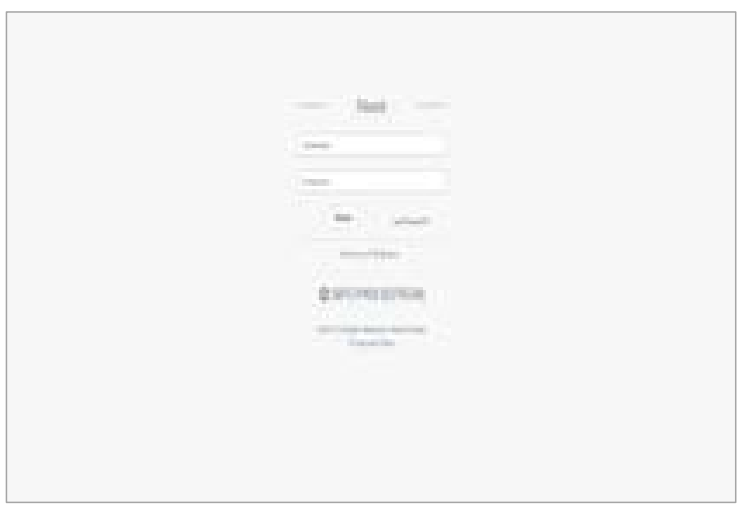

Gambar 37 Tampilan halaman login

\section{Halaman Dashboard}

Halaman ini muncul setelah proses login berhasil, halaman ini berisikan berisikan informasiinformasi berupa total data, total transaksi dan grafik transaksi pada bulan berjalan dan juga berisi menumenu pada sistem informasi. Dapat dilihat pada Gambar 38.

\section{Halaman Daftar Obat}

Halaman ini digunakan untuk melihat daftar obat yang telah diinput. Ada beberapa tombol pada 


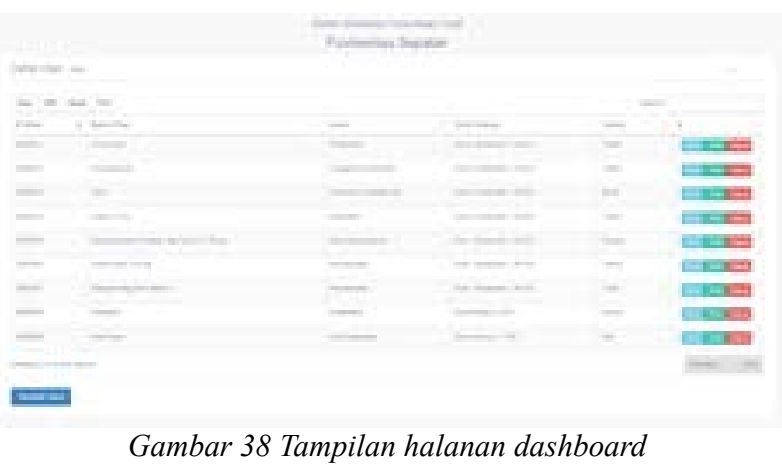

halaman ini, seperti tombol Detail untuk melihat detail obat per ID Obat, tombol Ubah untuk mengubah data obat per ID Obat, tombol Hapus untuk menghapus data obat per ID Obat, Search untuk pencarian data, tombol Print untuk mencetak tabel daftar obat dan tombol Tambah Obat untuk melakukan transaksi tambah obat. Dapat dilihat pada Gambar 39.

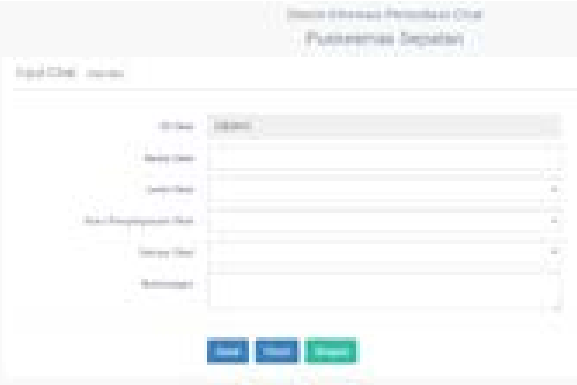

Gambar 39 Tampilan halaman daftar obat

\section{Halaman Tambah Obat}

Halaman ini digunakan untuk melakukan transaksi tambah data obat, terdapat 6 field yang harus diisi. Ada 3 tombol pada halaman ini, seperti tombol Simpan untuk menyimpan transaksi setelah field terisi, tombol Reset untuk menghapus semua field yang telah terisi dan tombol batal untuk kembali ke halaman Daftar Obat. Seperti pada Gambar 40.

\section{Halaman Persediaan Obat}

Halaman ini digunakan untuk melihat daftar persediaan obat yang telah diinput. Ada beberapa tombol pada halaman ini, seperti tombol Detail untuk melihat detail obat per ID Obat dan tombol Detail

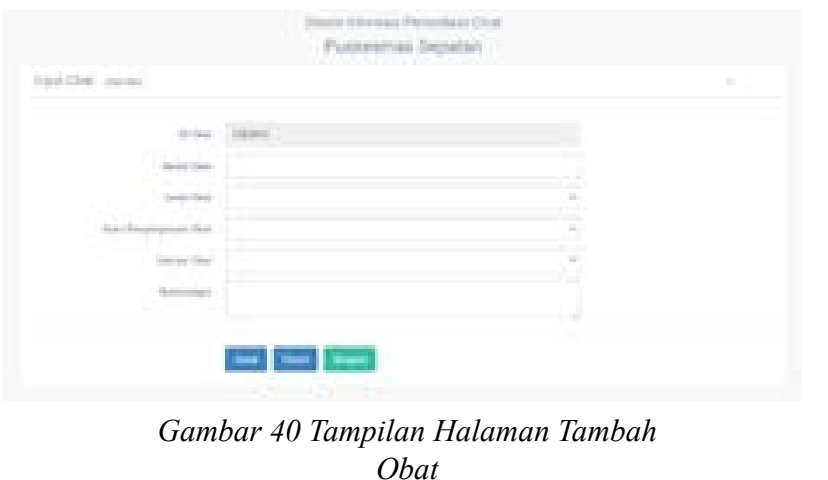

pada bagian bawah untuk melihat semua daftar detail persediaan obat. Dapat dilihat pada Gambar 41.

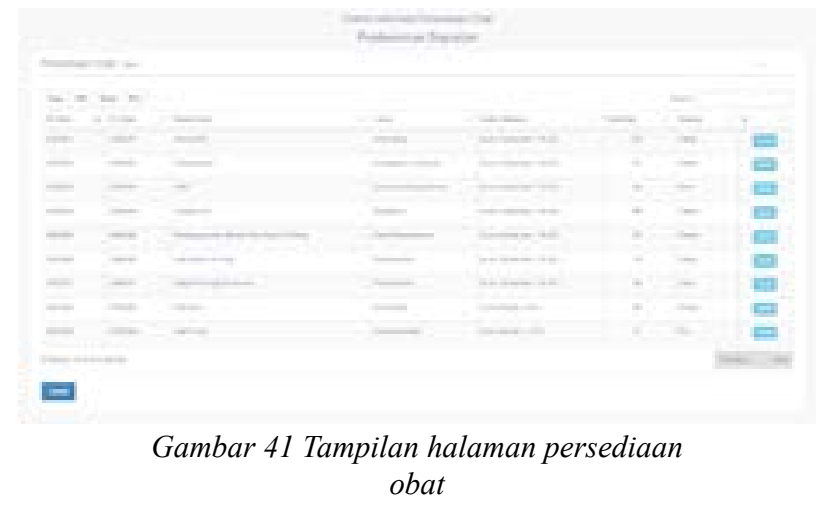

\section{Halaman Persediaan Obat Detail}

Halaman ini digunakan untuk melihat semua detail persediaan berdasarkan. Ada 1 tombol yaitu tombol Kembali yang berfungsi untuk kembali ke halaman persediaan obat. Seperti pada Gambar 42.

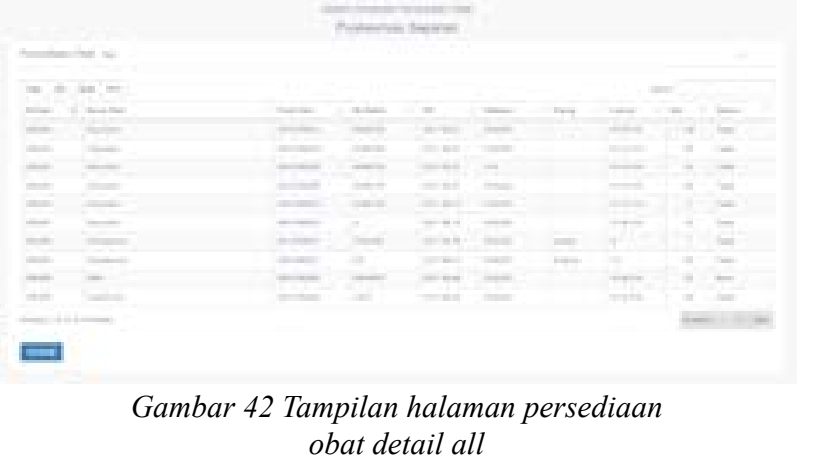

\section{Halaman Pemesanan Obat}

Halaman ini digunakan untuk melakukan transaksi pemesanan obat, terdapat 12 field yang harus diisi. Ada 3 tombol pada halaman ini, seperti tombol Simpan untuk menyimpan transaksi setelah field terisi, tombol Reset untuk menghapus semua field yang telah terisi dan tombol batal untuk kembali ke halaman Daftar Obat. seperti pada Gambar 43.

\section{Halaman Ubah Lokasi Obat}

Halaman ini digunakan untuk melakukan transaksi perubahan lokasi data obat, terdapat 8 field yang harus diisi. Ada 3 tombol pada halaman ini,

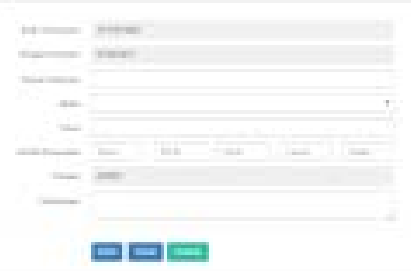

Gambar 43 Tampilan halaman pemesanan obat 
seperti tombol Simpan untuk menyimpan transaksi setelah field terisi, tombol Reset untuk menghapus semua field yang telah terisi dan tombol batal untuk kembali ke halaman Daftar Obat. Dapat dilihat pada Gambar 44.

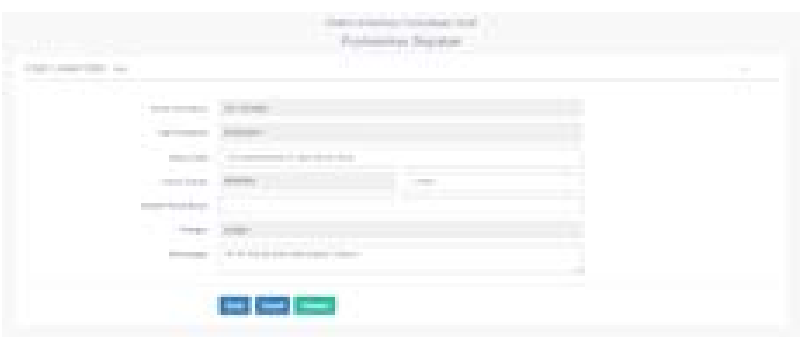

Gambar 44 Tampilan halaman ubah lokasi obat

\section{Halaman Penerimaan}

Halaman ini digunakan untuk melakukan transaksi penerimaan obat, terdapat 12 field yang harus diisi. Ada 4 tombol pada halaman ini, seperti tombol Tambah untuk menambah data obat yang akan diinput, tombol Simpan untuk menyimpan transaksi setelah field terisi, tombol Reset untuk menghapus semua field yang telah terisi dan tombol batal untuk kembali ke halaman Daftar Obat. Dapat dilihat pada Gambar 45.

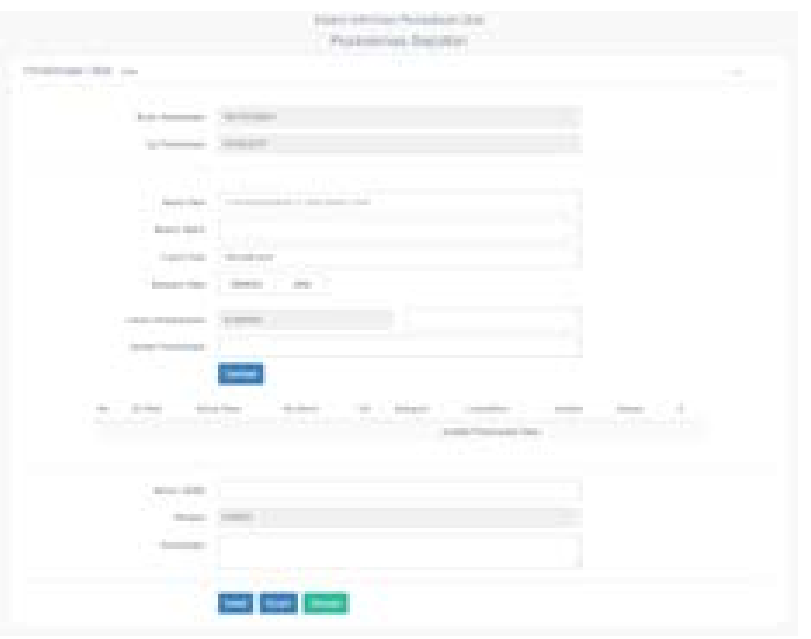

Gambar 45 Tampilan halaman penerimaan obat

\section{Halaman Pengeluaran Obat}

Halaman ini digunakan untuk melakukan transaksi pengeluaran obat, terdapat 11 field yang harus diisi. Ada 4 tombol pada halaman ini, seperti tombol Tambah untuk menambah data obat yang akan dikeluarkan, tombol Simpan untuk menyimpan transaksi setelah field terisi, tombol Reset untuk menghapus semua field yang telah terisi dan tombol batal untuk kembali ke halaman Daftar Obat. Dapat dilihat pada Gambar 46.

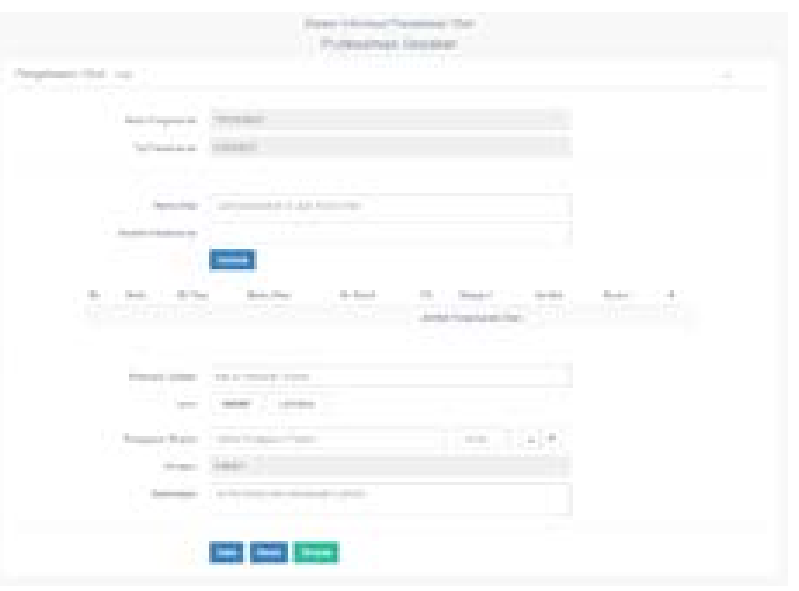

Gambar 46 Tampilan halaman pengeluaran obat

\section{K. Implementasi Cetak Laporan}

Berikut ini hasil cetak dari beberapa transaksi yang dilakukan menggunakan Sistem Informasi Persediaan Obat Puskesmas Sepatan:

\section{Laporan Penerimaan Obat}

Laporan Penerimaan Obat didapat dari proses transaksi penerimaan obat yang dilakukan oleh petugas berdasarkan dokumen SBBK dan data obat yang diterima dari Dinas Kesehatan. Dapat dilihat pada Gambar 47.
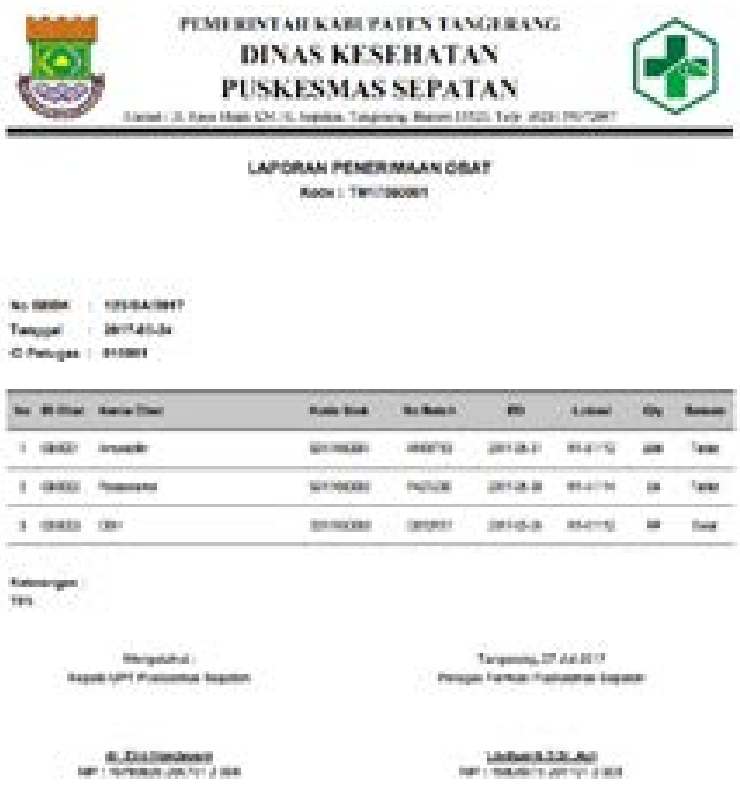

Gambar 47 Hasil cetak laporan penerimaan obat

\section{Laporan Pengeluaran Obat}

Laporan Pengeluaran Obat didapat dari proses transaksi pengeluaran obat yang dilakukan oleh petugas berdasarkan peresepan yang dilakukan dokter yang diserahkan oleh pasien. Dapat dilihat pada Gambar 48. 


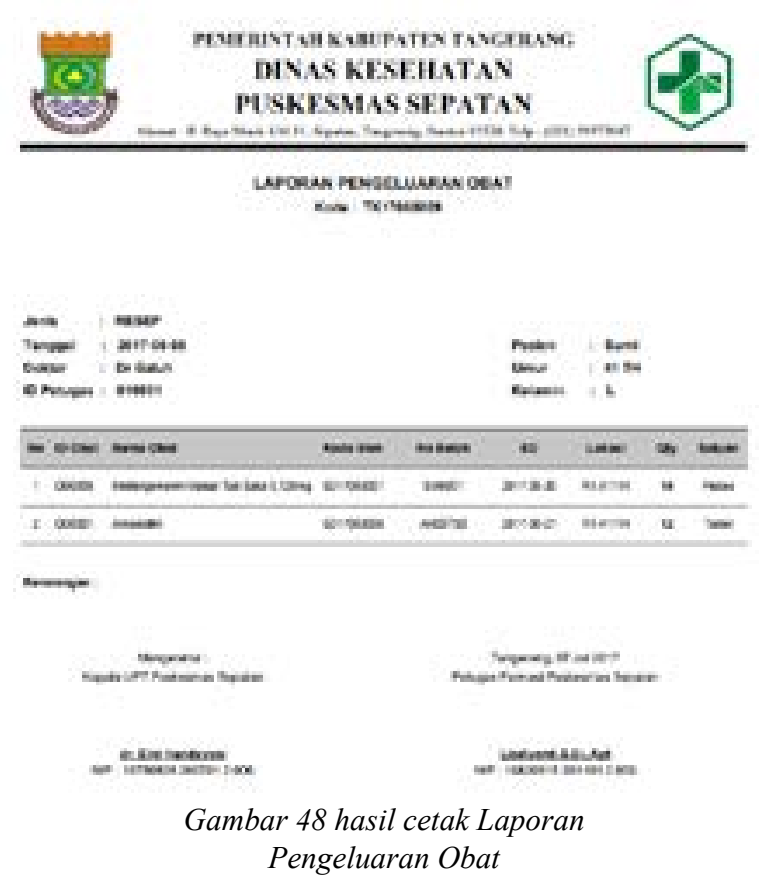

\section{Laporan Pengeluaran Harian}

Laporan Pengeluaran Obat Harian didapat dari total transaksi pada proses transaksi pengeluaran obat yang dilakukan oleh petugas selama satu hari berdasarkan tanggal pengeluaran. Dapat dilihat pada Gambar 49.

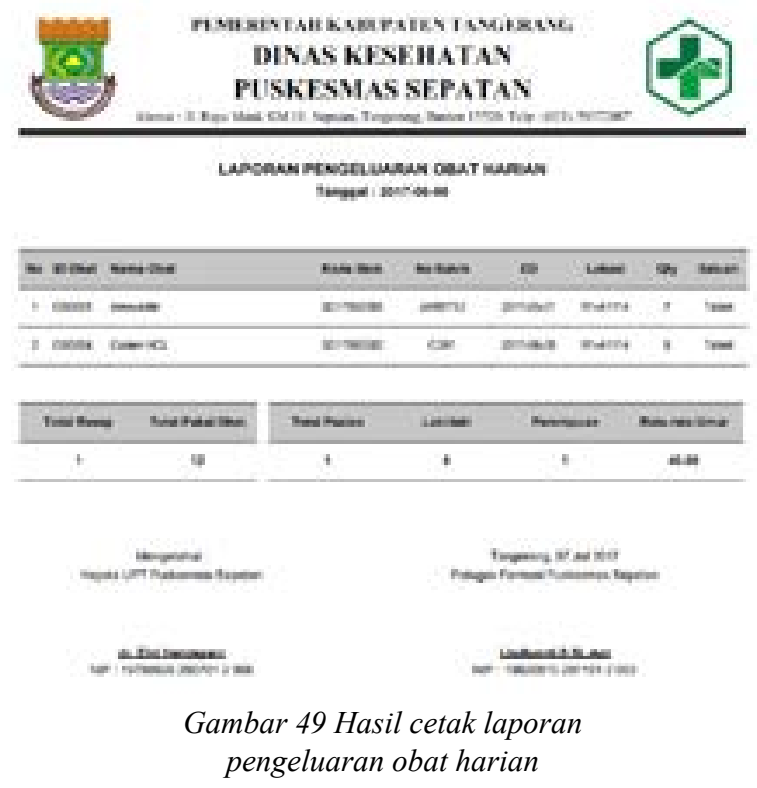

\section{Laporan Ubah Lokasi Obat}

Laporan Perubahan Lokasi Obat didapat dari proses transaksi perubahan lokasi obat yang dilakukan oleh petugas berdasarkan list perubahan yang sudah disetujui. Dapat dilihat pada Gambar 50.

\section{Laporan Pemesanan Obat}

Laporan Pemesanan Obat didapat dari proses transaksi pemesanan obat yang dilakukan oleh petugas pada akhir bulan. Seperti pada Gambar 51.

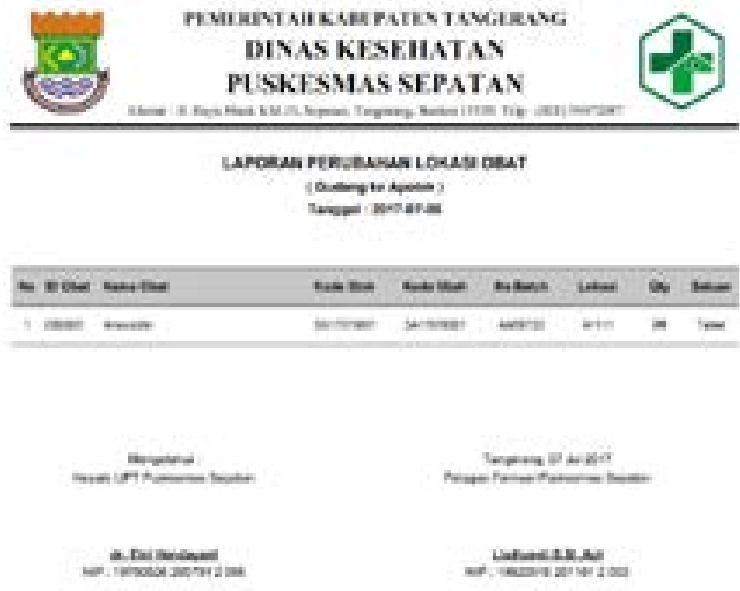

Gambar 50 Hasil cetak laporan perubahan lokasi obat

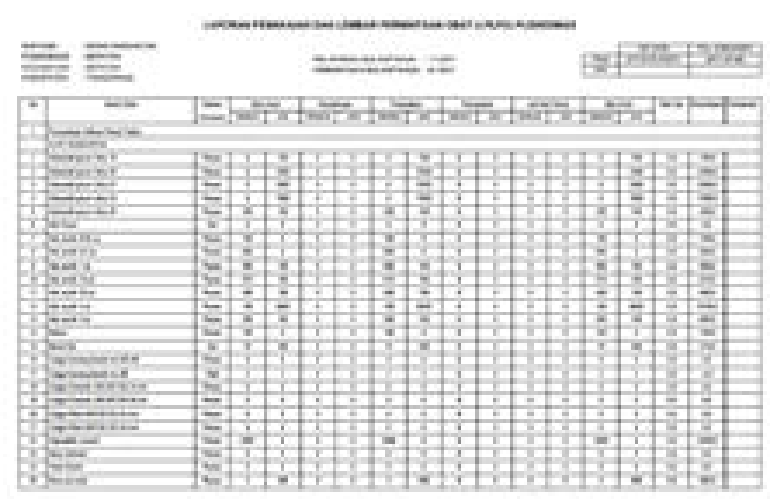

Gambar 51 Hasil cetak laporan pemesanan obat

\section{Laporan Narkotika}

Laporan Narkotika Obat didapat dari semua proses transaksi obat yang dilakukan oleh petugas berdasarkan penggolongan obat yaitu jenis Narkotika dan Psikotropika. Dapat dilihat pada Gambar 52.

\section{Pengujian Sistem}

Sebelum perangkat lunak diserahkan ke pemilik, perangkat lunak harus dievaluasi untuk menjamin telah memenuhi kebutuhan - kebutuhan fungsional dan non - fungsional.

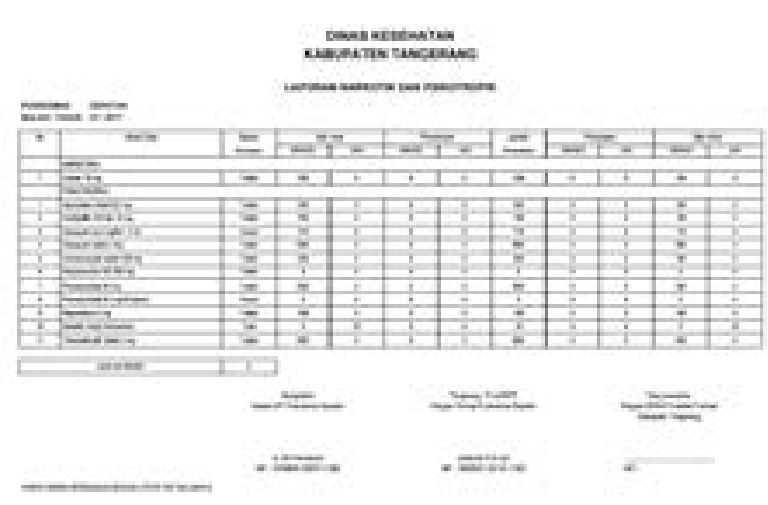

Gambar 52 Hasil cetak laporan narkotika 
Tabel 3 List Pengujian Sistem Informasi Persediaan Obat

\begin{tabular}{|c|c|c|}
\hline Bagian & Menu Uji & Detail Pengujian \\
\hline & \multirow{2}{*}{ Login } & Verifikasi Username \\
\hline & & Verifikasi Password \\
\hline \multirow{6}{*}{ Obat } & $\begin{array}{l}\text { Tambah } \\
\text { Data }\end{array}$ & Tambah data Obat \\
\hline & \multirow{3}{*}{ Lihat Data } & Pencarian data \\
\hline & & Ubah data \\
\hline & & Hapus data \\
\hline & \multirow{2}{*}{ Cetak Data } & Cetak semua data \\
\hline & & Cetak data berdasarkan pencarian \\
\hline \multirow{3}{*}{ Penerimaan } & \multirow{2}{*}{ Transaksi } & Tambah Transaksi Penerimaan \\
\hline & & Lihat List Transaksi Penerimaan \\
\hline & Laporan & $\begin{array}{l}\text { Cetak Laporan Transaksi } \\
\text { Penerimaan }\end{array}$ \\
\hline \multirow{2}{*}{$\begin{array}{l}\text { Perubahan } \\
\text { Lokasi }\end{array}$} & Transaksi & Tambah Transaksi Perubahan \\
\hline & Laporan & $\begin{array}{l}\text { Cetak Laporan Transaksi } \\
\text { Perubahan }\end{array}$ \\
\hline \multirow{3}{*}{ Pengeluaran } & \multirow{2}{*}{ Transaksi } & Tambah Transaksi Pengeluaran \\
\hline & & Lihat List Transaksi Pengeluaran \\
\hline & Laporan & $\begin{array}{l}\text { Cetak Laporan Transaksi } \\
\text { Pengeluaran }\end{array}$ \\
\hline \multirow{3}{*}{ Pemesanan } & \multirow{2}{*}{ Transaksi } & Tambah Transaksi Pemesanan \\
\hline & & Lihat List Transaksi Pemesanan \\
\hline & Laporan & $\begin{array}{l}\text { Cetak Laporan Transaksi } \\
\text { Pemesanan }\end{array}$ \\
\hline \multirow{6}{*}{ Persediaan } & \multirow{3}{*}{ Lihat Data } & $\begin{array}{l}\text { Lihat dan Cari data obat di } \\
\text { Gudang }\end{array}$ \\
\hline & & Lihat dan Cari data obat di Apotek \\
\hline & & Lihat dan Cari semua data obat \\
\hline & \multirow{3}{*}{ Laporan } & Cetak Laporan Persediaan Gudang \\
\hline & & Cetak Laporan Persediaan Apotek \\
\hline & & Cetak Laporan Semua Persediaan \\
\hline \multirow{2}{*}{ Laporan } & \multirow{2}{*}{$\begin{array}{l}\text { Cetak } \\
\text { Laporan }\end{array}$} & $\begin{array}{l}\text { Cetak Laporan Penggunaan } \\
\text { Narkotik }\end{array}$ \\
\hline & & $\begin{array}{l}\text { Cetak Laporan Pengeluaran obat } \\
\text { harian }\end{array}$ \\
\hline
\end{tabular}

Pengujian perangkat lunak pada Sistem Informasi Persediaan Obat Puskesmas Sepatan yaitu dengan menggunakan pengujian black box. Pengujian black box berfokus pada persyaratan fungsional perangkat lunak yang dibuat. Berikut adalah butirbutir pengujian Sistem Informasi Persediaan Obat Puskesmas Sepatan. Dapat dilihat pada Tabel 3.

Setelah dilakukan pengujian oleh user yaitu Ibu Lisdiyanti,S.Si.,Apt. selaku petugas farmasi di Puskesmas Sepatan menggunakan pengujian blackbox didapatkan hasil bahwa semua butir yang diuji sesuai dengan harapan sehingga aplikasi dapat digunakan dalam proses bisnis selanjutnya.

\section{SIMPULAN}

Setelah melakukan penelitian, menganalisis, merancang dan mengembangkan Sistem Informasi
Persediaan Obat pada bab-bab sebelumnya, selanjutnya akan diberikan kesimpulan bagi Sistem Informasi Persediaan Obat Puskesmas Sepatan.

Berdasarkan hasil penelitian Sistem Informasi Persediaan Obat Puskesmas Sepatan yang dibangun menggunakan metode pengembangan prototype yang dimulai dengan analisis menggunakan flowchart, perancangan menggunakan Diagram UML dan bahasa pemrograman PHP dan basis data MySQL serta pegujian dengan Black Box, maka penulis memberikan kesimpulan sebagai berikut:

Dengan adanya sistem informasi persediaan obat yang telah dikembangkan maka petugas dapat melakukan pengelolaan data obat dan data stok obat dengan menjalankan proses transaksi input data obat, transaksi penerimaan, transaksi perubahan lokasi, transaksi pengeluaran dan transaksi pemesanan yang ada di sistem dan dari transaksi yang telah dilakukan petugas akan mendapatkan informasi berupa laporan, diantaranya laporan data obat, laporan penerimaan, laporan pengeluaran, laporan pengeluaran harian, laporan perubahan lokasi, laporan pemakaian dan lembar permintaan obat (LPLPO) dan laporan narkotika berdasarkan penggolongan obat yang ada pada data obat.

\section{DAFTAR RUJUKAN}

[1] Sucipto. Konsep dan Teknik Pengembangan Sistem berbasis Teknologi Informasi. Banten. 2010.

[2] A. Ristono. Manajemen Persediaan. Yogyakarta: Graha Ilmu, 2009. hlm 22.

[3] Y. Guswinanda. "Uji Disolusi Kaplet Omefulvin Produksi PT Mutifa”, Skripsi Sarjana Sains Universitas Sumatera Utara, Medan. 2011.

[4] Republik Indonesia. Peraturan Menteri Kesehatan Republik Indonesia Nomor 75 Tahun 2014 Tentang Pusat Kesehatan Masyarakat(Puskesmas). Kementerian Kesehatan, Jakarta. 2014.

[5] Indrajani. Database Design, Jakarta: PT. Elex Media Komputindo. 2015. Hlm. 36.

[6] R. S. Presman. Rekayasa Perangkat Lunak, Yogyakarta: Andi. 2007.

[7] Republik Indonesia. Peraturan Menteri Kesehatan Republik Indonesia Nomor 30 Tahun 2014 Tentang Standar Pelayanan Kefarmasian di Puskesmas. Kementerian Kesehatan, Jakarta. 2014. 